\title{
Mesoscale spatio-temporal dynamics of demersal assemblages of the Eastern Ionian Sea in relationship with natural and fisheries factors ${ }^{\star}$
}

\author{
Konstantinos Tsagarakis ${ }^{1, a}$, Chryssi Mytilineou ${ }^{1}$, John Haralabous ${ }^{1}$, Pascal LorancE ${ }^{2}$, \\ Chrissi-Yianna PoLITOU ${ }^{1}$ and John DoKos ${ }^{1}$ \\ ${ }^{1}$ Institute of Marine Biological Resources, Hellenic Centre for Marine Research, Agios Kosmas, 16610 Elliniko, Athens, Greece \\ 2 IFREMER, rue de l'Ile d'Yeu, BP 21105, 44311 Nantes Cedex 03, France
}

Received 12 March 2013; Accepted 30 October 2013

\begin{abstract}
Data from the MEDITS bottom trawl surveys in the Eastern Ionian Sea, covering a depth range of 28 to $845 \mathrm{~m}$ were analysed for the period 1998-2008. For each trawling location, environmental and geographical parameters were recorded, while biomass, abundance, biodiversity and size-based metrics were estimated for the total megafaunal community, as well as for four taxonomic sub-communities (Osteichthyes, Chondrichthyes, Crustacea and Cephalopoda) which were expected to respond differently to environmental changes and fishing. In addition, biomass and abundance of ten species selected based on commercial interest, depth range and life history traits were explored, with particular emphasis on deep-sea species. Fishing effort data collected during the study period were analysed and showed a decreasing trend, mainly due to a decrease in the activity of static nets. The relation between the estimated parameters and environmental and spatial factors, as well as temporal (interannual) effects and the effect of fishing effort were explored using generalized additive models (GAMs). Results of GAMs showed that depth and location explained much of the variation in community metrics, probably reflecting mesoscale spatial features and species/communities requirements. Even though the different communities and species exhibited variant patterns in bathymetric and spatial distribution, some common aggregation patterns in productive areas were identified. Despite the relatively short time series, GAMs were effective in detecting increasing trends for several metrics; taking into account spatial factors further contributed to attributing the remaining deviance to temporal effects. These trends were partly explained by the observed decline of fishing effort, which is further supported by the fact that negative relations between several metrics and fishing effort were identified, for some of the selected communities and populations. Abundance, species richness and maximum length proved the most informative metrics concerning the effect of fishing. The current decline in fishing effort in the area seems to be a move in the right direction and should be complemented by additional measures aiming to prevent allocation of effort towards the deep sea.
\end{abstract}

Keywords: Biodiversity / Fisheries impacts / Demersal community / Survey indicators / Temporal trends / Mediterranean Sea

\section{Introduction}

The need to evaluate the status of marine ecosystems, biological resources and the effect of environmental and anthropogenic factors has led to the development of numerous community metrics for use as important scientific and managerial tools (Rice 2000; Rochet and Trenkel 2003). However, the sensitivity of each indicator may vary with ecosystem and pressure type, thus metrics should be selected to best address the needs of each study (Rice 2003; Cury and Christensen 2005).

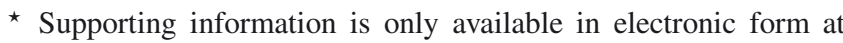
www.alr-journal.org

a Corresponding author: kontsag@hcmr.gr
}

Biomass and abundance indices and their spatio-temporal patterns of distribution may reflect community productivity and are often used to examine fisheries-induced (Rochet and Trenkel 2003) and other anthropogenic changes. Although their usefulness for assessing fishing impacts is questionable, species diversity metrics remain widely used because of (i) the declarations of several organizations on the needs to conserve biodiversity and (ii) the debate on the dependence of ecosystem functions and stability on species diversity (Rochet and Trenkel 2003). In addition, size-based indicators (e.g., mean or maximum lengths, percentiles of the length frequency distribution) are analysed and monitored, mainly because they are sensitive to fishing mortality at population and community levels (Shin et al. 2005) and/or fisheries induced evolution towards 


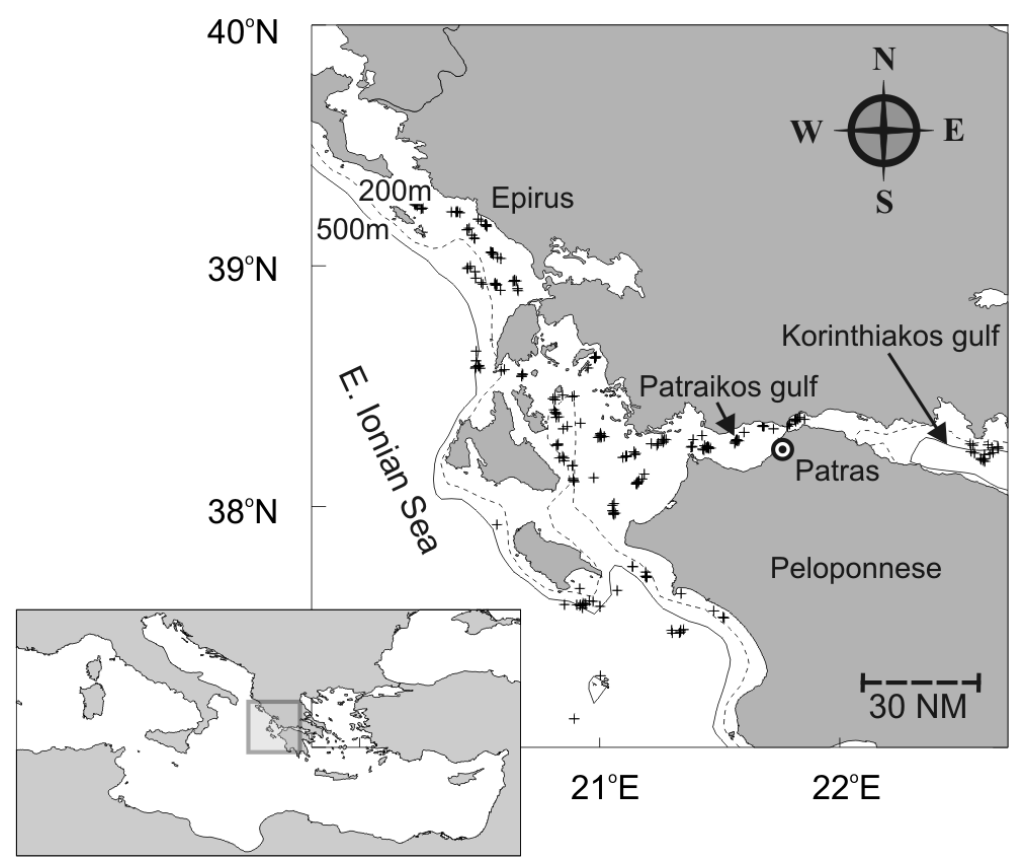

Fig. 1. Eastern Ionian Sea. Crosses indicate the positions of the MEDITS hauls. Isobaths are shown for $200 \mathrm{~m}$ (dashed line) and $500 \mathrm{~m}$ (solid line).

earlier reproduction (Law 2000). However, indirect effects through the food-web as well as environmental changes (e.g., eutrophication) may counteract the effect of fishing and thus the ability of such indices to detect fisheries effects (Rochet and Trenkel 2003). For example, the length distribution of the community is expected to be mostly related to the fishing effort; nevertheless it may also be sensitive to temporal recruitment variation. Thus, analysis of multiple indicators may be a better means of revealing the effects of fishing (Rice 2000). In addition, it can reveal patterns in species composition, relative abundance, distribution and migrations.

Spatial and bathymetric differences and patterns have been widely reported for the various metrics (e.g., Greenstreet and Hall 1996; Bianchi et al. 2000) and they mainly reflect species and/or life-stage preferences for specific habitats and environmental conditions (e.g., Rogers et al. 1999, Johnson et al. 2013) and, at the large scale, patterns in fishing pressure and/or productivity (Bianchi et al. 2000; Jennings et al. 2005). For example, in the Ionian Sea, differences in species distribution and abundance are evident both along the North/South and the West/North axes and were generally attributed to fishing activities, as well as hydrological characteristics (Politou et al. 2008a). Spatial patterns and depth gradients are also common in deep sea assemblages in terms of species composition, abundance and diversity (e.g., Gordon and Bergstad 1992; Koslow 1993; Lorance et al. 2002; Politou et al. 2003; D'Onghia et al. 2004; Dimech et al. 2008; Campbell et al. 2011). However, there doesn't seem to be a consistent pattern with depth; the metrics (e.g., number of species) may decrease (Moranta et al. 1998), increase (Magnussen 2002) or fluctuate (Sousa et al. 2006) depending on the ecosystem.

Furthermore, different taxonomic sub-communities are expected to show different responses on environmental gradients, including depth (Colloca et al. 2003; Politou et al. 2003).
Similarly they may respond differently to fishing or other pressures because (i) some may not be targeted by the fisheries, e.g., many species of crustaceans are not marketable in Greece (Machias et al. 2001; Thessalou-Legaki 2007) and (ii) they have different life history traits, e.g., chondrichthyes are generally large animals with low growth rate and fecundity and thus can only sustain low fishing mortality (Stevens et al. 2000), while most cephalopods are rather fast growing short-lived species (Caddy and Rodhouse 1998).

In the present study, we analysed the spatio-temporal patterns of a series of population and community metrics in the E. Ionian Sea throughout a 10 year period and studied their relationship with environmental and fishing factors. The study area extends over a wide bathymetric range and includes different species assemblages (Politou et al. 2003), which may respond differently to environmental variables and fishing intensity. However our goal was to analyse the system globally towards an integrative management approach; special emphasis was placed on the deep sea species, many of which are sensitive to fishing impact because of slow growth rates and low fecundity (Koslow et al. 2000). The aims of the study were to examine (i) spatial and temporal variation in the communities and their relationship with environmental variables and temporal trends in fishing activity and (ii) which metrics, taxonomic groups and/or species are more sensitive to fishing and can provide important information concerning its effect. We also discuss the management implications of our findings.

\section{Materials and methods}

\subsection{Study area and fishing activity}

The Eastern Ionian Sea (Fig. 1) is characterized by complex hydrography (Theocharis et al. 1993) and topography 
since it includes numerous small and large islands, semienclosed gulfs and open waters. The continental shelf is narrow, especially to the western side of the area of this study while it is more extended in the semi-enclosed areas, with the exception of the deep Korinthiakos Gulf (Fig. 1). The Eastern Ionian is an oligotrophic sea, reflecting the overall oligotrophic condition of the Mediterranean Sea, the narrowness of the continental shelf and the regional circulation (Theocharis et al. 1993; Siokou-Frangou et al. 2010), with productivity varying locally, being higher in semi-enclosed gulfs than in offshore waters (Ramfos et al. 2006). As a consequence, spatial distributions of species and taxonomic groups have been found to be patchy (Politou et al. 2003; Politou et al. 2008b; Tserpes et al. 2008). Fisheries in the area are multi-species and multigear and most of the fleets operate on the shelf. However, there is some trawling for deep-sea shrimps (Aristaeomorpha foliacea and Aristeus antennatus), as well as longlining and gillnetting for blackspot seabream, Pagellus bogaraveo, and hake, Merluccius merluccius down to about $800 \mathrm{~m}$ (Mytilineou and Machias 2007). Overall, the main fishing activity involves static nets, which catch $63 \%$ of the landings (62\% of Osteichthyes, $47 \%$ of Chondrichthyes, $84 \%$ of Cephalopods and $72 \%$ of Crustaceans) in the area (Anon. 2008). Bottom longlines catch approximately $47 \%$ of Chondrichthyes and $\sim 10 \%$ of total landings while bottom trawls catch $27 \%$ of Crustaceans and $\sim 5 \%$ of total landings (Anon. 2008). The remaining landings are mainly pelagic species, which are not included in the current analysis, and are caught with purse seines and pelagic longlines. Most of the commercial stocks were already considered overfished during the 1990s (Politou 2007) while the status of some, such as the red mullet (Mullus barbatus), striped mullet (M. surmuletus) and picarel (Spicara smaris) has improved in recent years (Anon. 2012; STECF 2012).

\subsection{Data}

Catch data from the MEDITS bottom trawl surveys in the E. Ionian Sea (including Patraikos and Korinthiakos Gulfs, Fig. 1) during summer in the periods 1998-2001, 2003-2006 and 2008 were used in this study. Existing MEDITS data for the years before 1998 were not considered since the survey design was improved in that year and we chose to be more consistent instead of including possible sampling biases. The MEDITS survey, which targets fish, crustaceans and cephalopods, follows a standardized protocol with fixed trawl locations (stations) and haul durations of 30 and $60 \mathrm{~min}$ in shallow $(<200 \mathrm{~m})$ and deep (>200 m) waters, respectively (Bertrand et al. 2002a). Catches are sorted to the species level and total biomass and numbers of individuals per species are recorded. The sizes (total length of fish, carapace length of crustaceans and mantle length of cephalopods to the $\mathrm{mm}$ ) of all individuals of each species, or of a representative sample (at least 50 individuals, according to the MEDITS protocol) in cases when catches are high, are measured.

A CTD (until 2001: Sea-Bird 19; from 2003: Sea-Bird $19+$ SeaCat profiler v3.0) was used to measure the vertical temperature and salinity profiles at each station. In total, 241 hauls at depths of 28 to $845 \mathrm{~m}$ were analysed, representing approximately 28 hauls each year. Some hauls had to be excluded because of missing environmental data.

Days-at-sea of gears targeting the demersal community (bottom trawls, longlines and static nets) from five ports in the area defined in the framework of the EU Data Collection Regulation (DCR) and other studies in support of the Common Fishery Policy ("Patterns and propensities in Greek fishing effort and catches", "Investigation of the fishing effort of the Greek commercial fishery", Anon. 2001) were used to estimate total fishing effort for each year during the study period (Labropoulou 2007; Anon. 2008). In the Ionian Sea, trip duration is always less than $24 \mathrm{~h}$, thus days-at-sea corresponds to actual fishing days. Due to the multi-species nature of the fisheries, most species are targeted by several gears; thus, the total fishing effort (sum of the effort of each gear) was considered a more appropriate representation of the actual fishing pressure exerted on the megafaunal community.

\subsection{Data analysis}

Trends in fishing effort for the three gears considered, as well as for the total fishing effort, were examined with linear regressions.

For each sampling station, after excluding pelagic species occurring incidentally in the catches, abundance and biomass were standardized per hauled area $\left(\mathrm{km}^{-2}\right)$ using the swept area method from the MEDITS protocol (Bertrand et al. 2002a,b), i.e., taking into account wing spread and the distance travelled by the trawl. Based on the standardized values, a series of community and diversity metrics was calculated for each year to assess the impact of environmental, fishing and spatio-temporal factors on the mega-faunal community in the E. Ionian Sea. Specifically, we estimated (i) values of biomass and abundance indices $\left(\mathrm{kg} \mathrm{km}^{-2}\right.$ and $\mathrm{N} \mathrm{km}^{-2}$, respectively) which were natural $\log$ transformed to reduce the effect of extreme values, (ii) three diversity indices from Hill's series $\left(N_{0}, N_{1}\right.$ and $N_{2}$; Hill 1973) and (iii) four size-based indicators $\left(L_{\text {mean }}\right.$ : mean length; $L_{\max }$ : maximum length; $L_{0.05}$ : length of the $5 \%$ of the length frequency of the community; $L_{0.95}$ : length of the $95 \%$ of the length frequency of the community). Concerning the diversity metrics, $N_{0}$ is the number of species, $N_{1}$, the exponential of Shannon $H^{\prime}$ index, is more sensitive to changes in rare species, and $N_{2}$, the inverse of Simpson's evenness index, is more sensitive to abundant species and to the evenness of the community (Greenstreet and Hall 1996; Greenstreet and Rogers 2006; and references therein). Primer5 software (Clarke and Warwick 1994) was used to calculate these metrics, which were estimated for the whole benthodemersal megafaunal community, as well as for four taxonomic sub-communities i.e. Osteichthyes, Chondrichthyes, Crustaceans and Cephalopods.

Further, we calculated the log abundance and biomass for 10 abundant benthic and demersal populations, which were frequently present, i.e., in at least $15 \%$ of the hauls, and were selected based on the following criteria: commercial interest, depth range (mainly deep sea species) and life history (slow growth and/or low fecundity, e.g., Chondrichthyes) in order to represent as many species categories as possible. Specifically, we included (i) species of both high (e.g., 
Table 1. List of species considered and their main characteristics. Depth range refers to the bathymetric distribution of the species in the study area; main range is also indicated in parenthesis.

\begin{tabular}{|c|c|c|c|c|c|}
\hline Scientific name & Common name & $\begin{array}{c}\text { Depth range }(\mathrm{m}) \\
\text { (main range) }\end{array}$ & Behaviour & $\begin{array}{c}\text { Commercial } \\
\text { interest }\end{array}$ & $\begin{array}{c}\text { Occurrence } \\
(\%)\end{array}$ \\
\hline \multicolumn{6}{|l|}{ Osteichthyes } \\
\hline Pagellus bogaraveo & Blackspot seabream & $42-655(>300)$ & demersal & High & 27.4 \\
\hline Helicolenus dactylopterus & Blackbelly rosefish & $98-692(>300)$ & benthic & Medium & 34.9 \\
\hline Merluccius merluccius & Hake & 30-735 (all) & demersal & High & 85.5 \\
\hline Lepidorhombus boscii & Four-spot megrim & $100-659(>250)$ & benthic & High & 23.7 \\
\hline Spicara smaris & Picarel & $28-337(<150)$ & demersal & Medium & 47.7 \\
\hline \multicolumn{6}{|l|}{ Chondrichthyes } \\
\hline Squalus blainville & Longnose spurdog & $77-659(>250)$ & demersal & Medium & 23.2 \\
\hline Raja clavata & Thornback ray & $36-659(<350)$ & demersal & Medium & 52.3 \\
\hline \multicolumn{6}{|l|}{ Crustacea } \\
\hline Nephrops norvegicus & Norway lobster & $66-647(100-550)$ & benthic & High & 16.6 \\
\hline Plesionika heterocarpus & Arrow shrimp & $97-655(250-550)$ & demersal & No & 20.3 \\
\hline Liocarcinus depurator & Blue-leg swimcrab & $36-586(<150)$ & benthic & Low & 37.3 \\
\hline
\end{tabular}

Merluccius merluccius hake, Nephrops norvegicus Norway lobster) and low (e.g., Plesionika heterocarpus arrow shrimp, Liocarcinus depurator blue-leg swimcrab) commercial interest, (ii) deep sea (e.g., Pagellus bogaraveo blackspot seabream, Helicolenus dactylopterus blackbelly rosefish, Lepidorhombus boscii four-spot megrim) and shallow water (e.g., Spicara smaris picarel) species and (iii) two abundant chondrichthyans (Squalus blainville longnose spurdog, Raja clavata thornback ray). Commercial interest was defined based on the records of Hellenic Statistical Service. Depth range comes from the MEDITS survey and species behaviour was defined based on the literature, remotely operated vehicle (ROV) observations and the authors' experience. The main ecological characteristics of these species, as well as their commercial interest, are listed in Table 1. We did not consider size-based metrics for these species since in some stations their abundance was too low to derive reliable length distribution and length metrics.

We used generalized additive models, GAMs, to explore the relationships between the aforementioned population and community metrics and (i) bottom depth, (ii) geographical location at haul positions, i.e. latitude, longitude and their interaction, (iii) temperature and salinity averaged for the $5 \mathrm{~m}$ layer above the seabed in each station, (iv) time (year) and (v) fishing effort (expressed as total days-at-sea for all gears combined during the year of sampling). The model we applied was of the form:

$$
\begin{aligned}
E(\text { metric })= & s(\text { Depth })+s(\text { Latitude })+s(\text { Longitude }) \\
& +s(\text { Latitude } * \text { Longitude })+s(\text { Temperature }) \\
& +s(\text { Salinity })+s(\text { Year })+s(\text { Fishingeffort })
\end{aligned}
$$

where "s" is the smooth function and * denotes interaction.

A Gaussian distribution and identity link were assumed and the natural cubic spline smoother was used for the independent variable smoothing and fitting GAM. The "mgcv" package in the R statistical software (v. R2.13.1; R Development Core Team 2011) was used to apply GAMs (Wood 2006). The correlation among the explanatory variables was low (correlation coefficient $<|0.2|$, except in the case of depth with temperature (correlation coefficient $=-0.48$ ) and fishing effort with year (correlation coefficient $=-0.48$ ). Since fishing effort values were aggregated annually, either year or effort was considered in the model, also given their correlation. Concerning geographical coordinates, we included either the effect of the interaction of latitude with longitude or separately latitude and/or longitude in the models. Only significant terms were considered for each model. Validation graphs (e.g., QQ-plot and residual plot against the original explanatory variables) were inspected in order to detect any model misspecification. We explored the effect of each explanatory variable alone, as well as the combined effects of all variables in order to detect the best model explaining the variation in the data. The final models were selected based on the deviance explained and the minimization of the Akaike information criterion $(A I C)$ (Burnham and Anderson 2002), while models with $\triangle A I C<2\left(\triangle A I C=A I C_{\mathrm{i}}-A I C_{\min }\right.$, where $A I C_{\mathrm{i}}$ is the $A I C$ of the custom model and $A I C_{\min }$ is the minimum AIC observed) were also considered as substantially explaining the data (Burnham and Anderson 2002). In some cases, in order to further identify temporal effects or the effect of fisheries, an additional model was also considered where fishing effort or year was also significant and the model more complex but not the best, provided that it explained substantial amount of the observed variability and that the increase in $A I C$ in comparison to $A I C_{\min }$ was lower than $2 \%$. Furthermore, in order to derive a robust conclusion on whether the temporal effects revealed by GAMs showed increasing, decreasing or no particular trend, we examined the Pearson's correlation of these effects with year.

\section{Results}

The examination of the fishing effort showed that total effort has declined with a statistically significant negative trend since the year $2000\left(y=-18.058 x+36933, R^{2}=0.626\right.$, $p$-value $=0.034$; Fig. 2). This decline is mainly due to a decrease in fishing effort of static nets, $(y=-21.513 x+43770$, $R^{2}=0.877, p$-value $=0.002 ;$ Fig. 2 ). Fishing efforts of bottom trawls and longlines have also declined since 2003, but without presenting a statistically significant trend. 
Table 2. GAMs of metrics of the total community of the E. Ionian Sea: deviance explained (\%) by each one of the explanatory variables when considered alone, and total deviance explained $(\%)$ by the final selected model(s). The best models were selected based on the minimization of $A I C$ and corresponding $\triangle A I C$. Bi: biomass; $N$ : abundance; $N_{0}, N_{1}$ and $N_{2}$ : diversity indices from Hill's series; for definition of the remaining length metrics see text; $D$ : depth; $S$ : salinity; $T$ : temperature; Lon: longitude; Lat: latitude; $Y$ : year; $E$ : fishing effort; ":" denotes interaction; “*” indicates statistically significant effect ( $p<0.05$ ); (a) principal model; (b): additional model; $r$ : Pearson's correlation coefficient of year with the effect of year.

\begin{tabular}{|c|c|c|c|c|c|c|c|c|c|c|c|}
\hline \multirow[b]{2}{*}{ Metrics } & \multicolumn{8}{|c|}{ Explanatory variables (deviance explained \%) } & \multicolumn{3}{|c|}{ Best model } \\
\hline & $D$ & $S$ & $T$ & Lat & Lon & Lat:Lon & $Y$ & $E$ & variables & dev. expl. \% & $r$ ( $p$-value) \\
\hline $\ln B i$ & $26.2 *$ & 1.4 & $32.8^{*}$ & $9.6^{*}$ & $36.9 *$ & $46.1 *$ & $6.4^{*}$ & $7.9^{*}$ & Lat:Lon $+T+Y$ & 59.9 & $1(<0.001)$ \\
\hline $\ln N$ & $45.6 *$ & $1.7^{*}$ & $48.5^{*}$ & $18.8 *$ & $53 *$ & $64.2 *$ & $5.3^{*}$ & 0.2 & Lat:Lon $+D+Y$ & 70.4 & $0.94(<0.001)$ \\
\hline$N_{0}$ & $49.8 *$ & 1.7 & $41.6 *$ & $14.6^{*}$ & $49.9 *$ & $62.9 *$ & 1.3 & 0.0 & Lat:Lon $+D+Y$ & 65.7 & $1(<0.001)$ \\
\hline$N_{1}$ & $17.4^{*}$ & $7.7^{*}$ & $10.5^{*}$ & $17.2^{*}$ & $14.4^{*}$ & $46.7 *$ & 0.0 & 0.1 & Lat:Lon & 46.7 & \\
\hline$N_{2}$ & $11.6^{*}$ & $7.4^{*}$ & $8.3 *$ & $15.3^{*}$ & $11.7^{*}$ & $39.7 *$ & 0.0 & 0.1 & Lat:Lon + D & 40.4 & \\
\hline$L_{\text {mean }}$ & $43.0^{*}$ & 0.0 & $52.4^{*}$ & $13 *$ & $62.9 *$ & $69.8^{*}$ & 1.7 & 2.5 & Lat:Lon $+Y$ & 71.6 & $0.78(<0.001)$ \\
\hline$L_{0.05}$ & $27.5^{*}$ & $13.5^{*}$ & $17.6^{*}$ & $17.6^{*}$ & $31.6 *$ & $46.2^{*}$ & 0.8 & 2.8 & Lat:Lon $+D+Y$ & 52.6 & $0.63(<0.001)$ \\
\hline$L_{0.95}$ & $36.3^{*}$ & 1.4 & $34.5^{*}$ & 2.2 & $40.4^{*}$ & $55.5^{*}$ & 0.7 & 3.1 & Lat:Lon + D & 56.5 & \\
\hline$L_{\max }$ & $21.9 *$ & 2.7 & $11.7 *$ & $15.5^{*}$ & $14.9 *$ & $37.3^{*}$ & 2.1 & 2.8 & $\begin{array}{l}\text { (a) Lat:Lon }+E \\
\text { (b) Lat:Lon }+Y\end{array}$ & $\begin{array}{l}40.6 \\
39.5\end{array}$ & $0.92(<0.001)$ \\
\hline
\end{tabular}

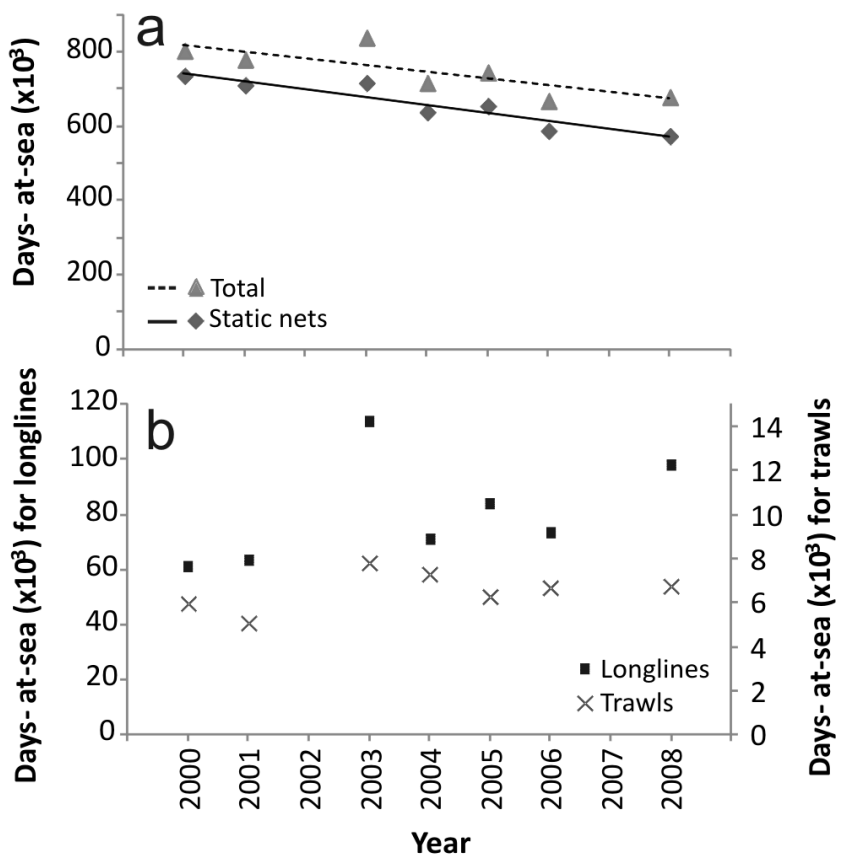

Fig. 2. Fishing effort (days-at-sea) in the E. Ionian Sea during the period 2000-2008. (a) Total fishing effort and fishing effort of static nets; (b) fishing effort of longlines (left axis) and trawls (right axis). Lines illustrate statistically significant trends.

Temperature in the $5 \mathrm{~m}$ layer above the seabed ranged from 13.5 to $21.5{ }^{\circ} \mathrm{C}$ throughout the study period, being relatively higher at shallow depths and always below $16^{\circ} \mathrm{C}$ in stations deeper than $100 \mathrm{~m}$. Salinity above the seabed ranged from and 36.4 to 44.2 , with $88 \%$ of the values being between 38.4 and 39.4. Even though these parameters varied locally, no spatio-temporal patterns, linear or non-linear, were identified for temperature and salinity.

The data set analysed comprised 248 species, including 128 Osteichthyes, 29 Chondrichthyes, 62 Crustacea and 29 Cephalopoda. The data used in GAM analysis, annual box plots of biomass, abundance and mean length of the total com- munity (all species combined) during the study period are presented in Figure 3. In addition, biomass, abundance indices and mean lengths of the four sub-communities examined (Osteichthyes, Chondrichthyes, Crustacea and Cephalopoda) are presented as annual box-plots in Figure S1 of the Appendix, while means and standard errors of these metrics for the 10 species examined are illustrated in Figure S2.

The final GAMs of the metrics of the total community explained $40-72 \%$ of the deviance (Table 2). The deviance explained by each factor alone may give a general idea on the distribution of explanatory power among the explanatory variables. In general, depth and geographical coordinates (the interaction of longitude with latitude) explained much of the deviance of the community metrics, when considered alone and in most cases they were included in the final selected models (Table 2, Fig. 4). The abundance increased slightly with depth to about $400 \mathrm{~m}$ and then decreased sharply. Diversity metrics, $N_{0}$ and $N_{2}$ decreased with depth, but a peak was apparent for species richness $\left(N_{0}\right)$ at around $400 \mathrm{~m}$ (Fig. 4). For $N_{1}$, the depth effect was not significant when added to the effect of geographical coordinates. $L_{0.05}$ also decreased with depth, revealing the existence of a higher proportion of small-sized individuals/species in deeper water between 300 and $700 \mathrm{~m}$ depth, though coexisting with a high proportion of large individuals/species, as revealed by the effect of depth on the $L_{0.95}$ which increased up to $500 \mathrm{~m}$. Local effects were observed for all the metrics examined. Positive effects on biomass corresponding to geographical coordinates in the Patraikos Gulf (approximately 38.3N/21.5E; see Figs. 1 and 4) were obvious, while diversities also maximized in the Patraikos Gulf and in areas eastern to the islands of the central E. Ionian Sea (approximately $38.5 \mathrm{~N} / 21 \mathrm{E}$; see Figs. 1 and 4). For several metrics, the effect of temperature taken alone was significant, but it was only included in the final model for biomass, which presented low values at low temperatures. On the contrary, salinity contributed very little to the deviance explained. The effect of year was significant only in two cases when considered alone (in biomass and abundance), but it was included as a significant factor in the finally selected models for six metrics. Specifically, increasing trends (positive correlation) were apparent for 

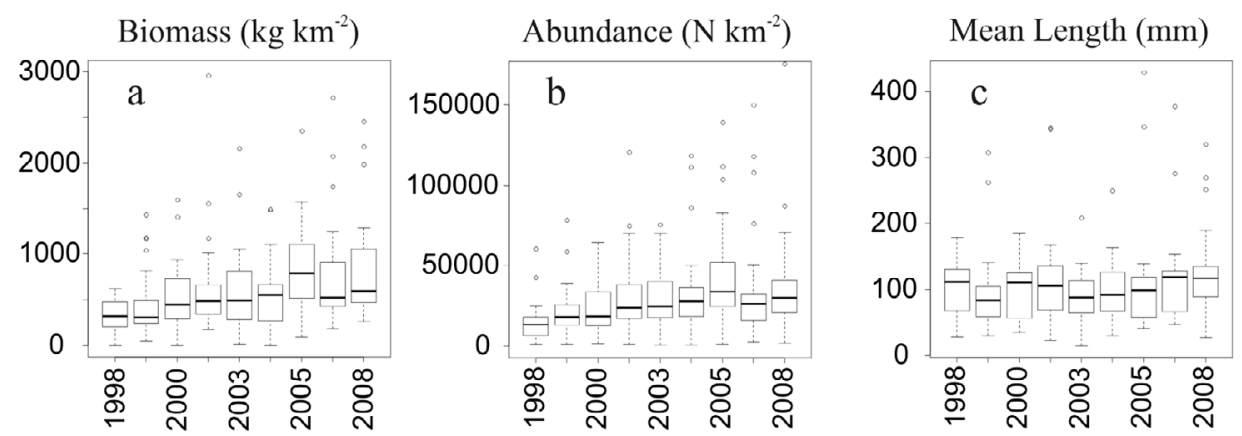

Fig. 3. Annual box-plots for biomass (a) and abundance (b) indices as well as mean length (c) of the total community.

abundance, biomass, $N_{0}, L_{0.05}, L_{\text {mean }}$ and $L_{\max }$, throughout the study period (Table 2, Fig. 4). Fishing effort contributed only to the selected model for $L_{\max }$, which declined with increasing effort (Fig. 4).

Geographical coordinates and depth were also the main factors in the selected models in the analysis of the Chondrichthyes sub-community (Table 3). GAMs fitted most of the metrics well (34-65\%), but did not adequately describe $L_{\text {mean }}$ and $L_{0.05}$, since the deviance explained was low $<22 \%$ ). Biomass and abundance were low on the continental shelf and peaked between 300 and $700 \mathrm{~m}$, decreasing with further depths. All diversity metrics were low between 0 and $200 \mathrm{~m}$ and increased sharply afterwards, with maxima at $400 \mathrm{~m}$ (Fig. S3). Positive effects on biomass and abundance were also obvious for areas corresponding to the Patraikos Gulf and to offshore areas (low longitudes). Increasing temporal trends were obvious for abundance, $N_{0}$ and $L_{\max }$. A clear negative relation of abundance with fishing effort and one not so obvious for $L_{\max }$ were revealed.

The GAMs for the Osteichthyes sub-community explained even higher percentages of the deviance (44-81\%; Table 3 ). As in previous analyses, geographical coordinates and depth contributed the most, but year or fishing effort was also included in several final selected models. Contrary to what was observed in Chondrichthyes, abundance and diversity metrics declined with depth, while $L_{0.95}$ increased. The remaining size-based metrics fluctuated presenting peaks at intermediate depths $\left(L_{\max }\right.$ at $200-600 \mathrm{~m} ; L_{\text {mean }}$ at $450 \mathrm{~m}$ and $700 \mathrm{~m}$; $L_{0.05}$ at depths $>200 \mathrm{~m}$ ). Although peaks in the different sizebased metrics are observed at different depths, it is noticeable that the lowest values are usually observed at shallower depths. Biomass and particularly abundance were maximal in Patraikos Gulf and off the coasts of Epirus. Biomass, abundance, number of species $\left(N_{0}\right)$ and $L_{\max }$ increased during the survey period, while $L_{\max }$ and $N_{0}$ decreased at increased fishing effort (Fig. S4).

The Crustaceans were more abundant at the continental slope between 200 and $700 \mathrm{~m}$ depth (Fig. S5). Their diversities reached maximum values at 400-500 $\mathrm{m}$ and showed a tendency to decrease in deeper waters $(>600 \mathrm{~m})$. All length metrics also increased with depth. Local effects were apparent for several metrics, however a common positive effect on biomass, abundance, diversities and $L_{\max }$ was observed for coordinates corresponding to areas to the east of the islands of the central E. Ionian Sea (approximately 38.5 N/21.2 E; see Figs. 1 and S5). The effect of year was included in the final models of six out of nine metrics (Table 3, Fig. S5). Biomass and abundance increased from 1998 to 2004 and decreased thereafter in combination with a decline of diversity $\left(N_{0}\right.$ and $\left.N_{1}\right)$. Overall, throughout the study period, no correlation was found between year and the effect of year on biomass, weak negative correlation was found for abundance while for diversity $\left(N_{0}\right.$ and $\left.N_{1}\right)$ a negative correlation was apparent (Table 3$)$. In contrast, $L_{\text {mean }}$ and $L_{0.05}$ showed an increasing trend throughout the whole period (positive correlation; Table 3). The effect of fishing effort was significant in only three cases: specifically, concerning the abundance and $N_{0}$, complex effects were detected consisting of an increase from low to intermediate values of fishing effort, a decline thereafter and a further increase in high effort values, while a clear negative effect was apparent for $L_{0.95}$ (Table 3, Fig. S5).

Depth was the main factor for most metrics applied to Cephalopods, and its effect was often stronger than the geographical effect, as implied by the \% deviance explained (Table 3). A negative effect was observed for abundance and biomass with increasing depth and similar effects were apparent with diversity metrics after a peak at around $300 \mathrm{~m}$ depth. In general, length metrics increased with depth and declined only in the deepest range below about $450 \mathrm{~m}$ (Fig. S6). Furthermore, all metrics decreased with increasing longitude. Year was significant for all metrics but $N_{1}$ and $N_{2}$ (Fig. S6), and a generalized increasing trend (positive correlation) was observed throughout the study period. Fishing effort was significant in an alternative model for $L_{\text {mean }}, L_{0.05}$ and $L_{0.95}$ only. For these metrics its effect was generally negative, although it fluctuated a great deal (Fig. S6).

The directions of change of the metrics examined for the total community and the sub-communities (i) throughout the study period and (ii) as a response to fishing effort are synthesized in Table 4. The directions of changes are based on the smooth terms shown in Figures 4 and S3-S6 and on alternative models to the best ones with year or fishing effort contributing as significant factors. In general, most metrics increased with year and decreased at high values of fishing effort for the whole community, as well as for the Osteichthyes, Chondrichthyes and Cephalopoda sub-communities (Table 4). Nevertheless, fishing effort was less frequently significant than year and in several cases there was no clear pattern. The combination of increasing trends throughout the study period and decreasing responses with fishing effort was strong for Chondrichthyes and 
a. $\ln (\mathrm{Bi})$

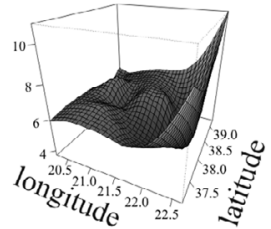

b. $\ln (\mathrm{N})$

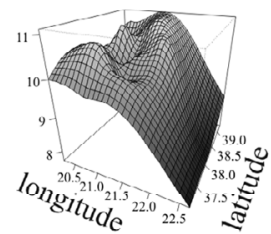

c. $\mathrm{N}_{0}$

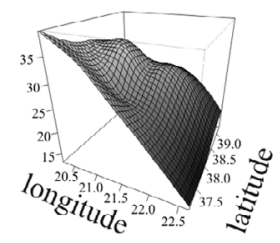

d. $\mathrm{N}_{1}$

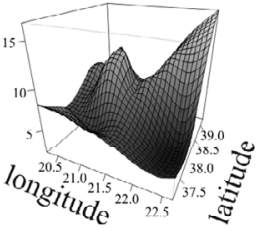

e. $\mathrm{N}_{2}$

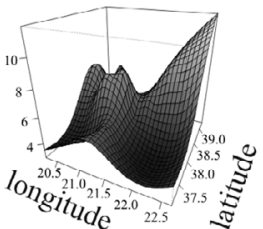

f. $L_{\text {mean }}$
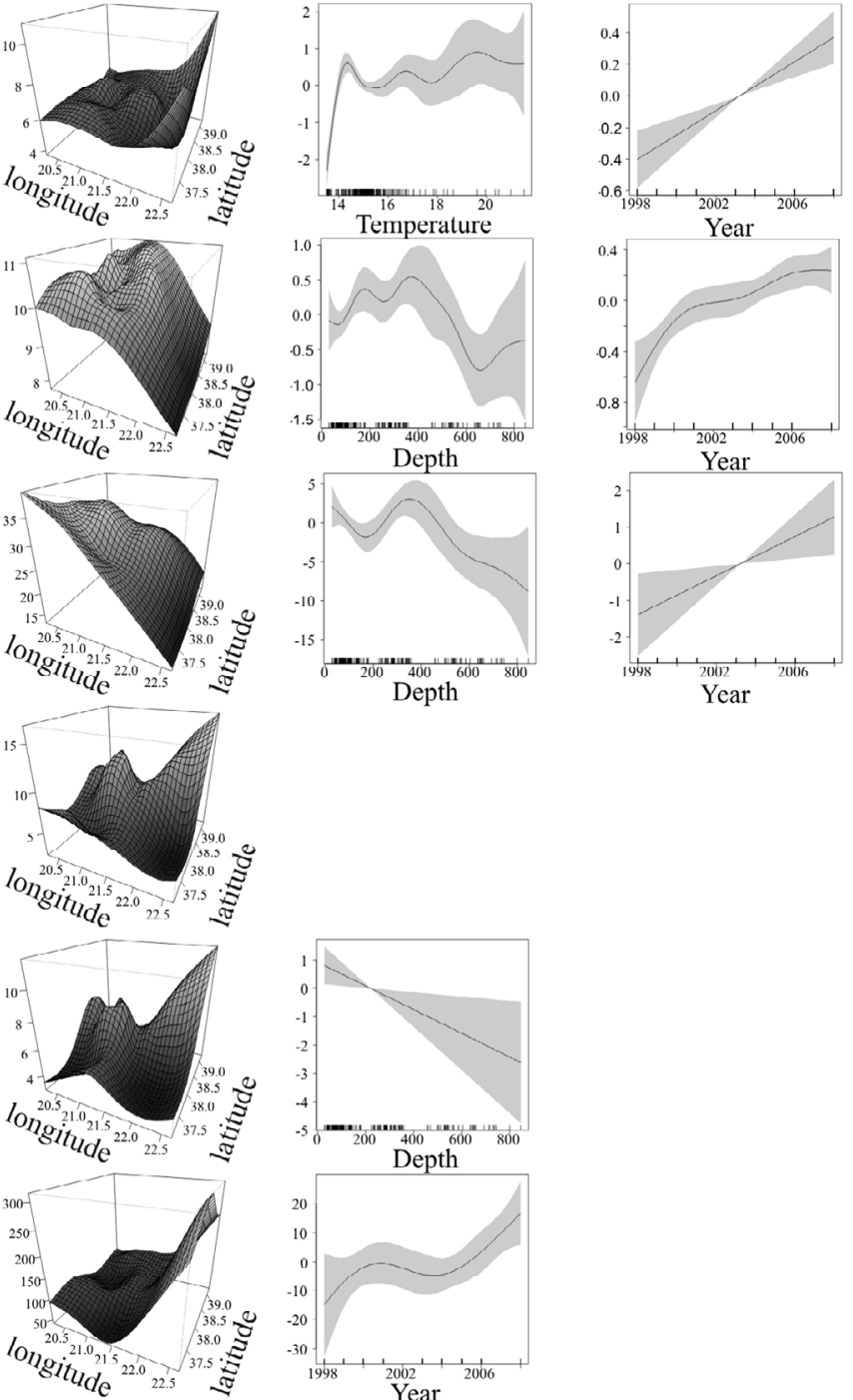

Year

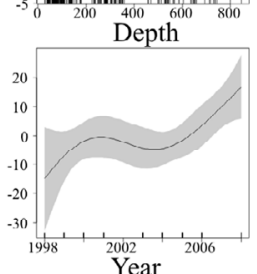

g. $\mathrm{L}_{0.05}$
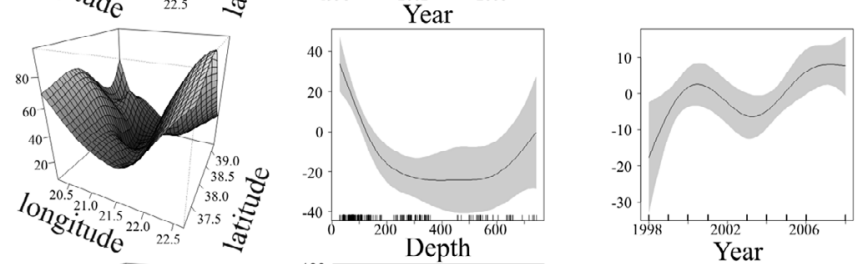

h. $\mathrm{L}_{0.95}$
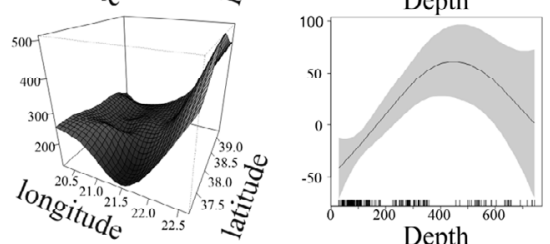

Year
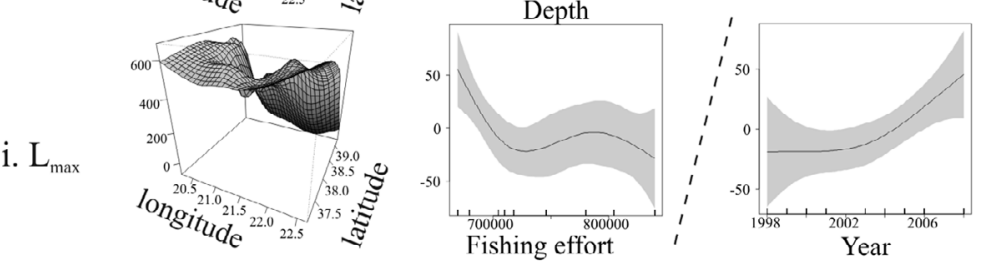

Fig. 4. Estimated smooth terms of the parameters contributing to the selected GAMs for metrics of the total community. $\ln (B i)$ : natural logarithm of biomass; $\ln (N)$ : natural logarithm of abundance; $N_{0}, N_{1}$ and $N_{2}$ : diversity indices from Hill's series; for definition of the remaining length metrics see text. Diagonal dashed lines indicate alternative models (see Table 2 for more information). Grey areas are $95 \%$ confidence intervals. Rug plots indicate the distribution of the observed values. 
Table 3. GAMs of metrics of the Chondrichthyes (A), Osteichthyes (B), Crustacean (C) and Cephalopod (D) sub-communities of the E. Ionian Sea: deviance explained (\%) by each one of the explanatory variables when considered alone, and total deviance explained (\%) by the final selected model(s). The best models were selected based on the minimization of AIC and corresponding $\triangle A I C$. Some additional ecologically interpretable models were selected and are indicated in italics. Bi: biomass; $N$ : abundance; $N_{0}, N_{1}$ and $N_{2}$ : diversity indices from Hill's series; for definition of the remaining length metrics see text; $D$ : depth; $S$ : salinity; $T$ : temperature; Lon: longitude; Lat: latitude; $Y$ : year; $E$ : fishing effort; “:” denotes interaction; “*” indicates statistically significant effect ( $p<0.05$ ); (a) principal model; (b): additional model; $r$ : Pearson's correlation coefficient of year with the effect of year.

\begin{tabular}{|c|c|c|c|c|c|c|c|c|c|c|c|}
\hline \multirow{2}{*}{ Metrics } & \multicolumn{8}{|c|}{ Explanatory variables (deviance explained \%) } & \multicolumn{3}{|c|}{ Best model } \\
\hline & $D$ & $S$ & $T$ & Lat & Lon & Lat:Long & $Y$ & E & variables & dev. expl. \% & $r(p$-value $)$ \\
\hline \multicolumn{12}{|c|}{ A. Chondrichthyes } \\
\hline $\ln B i$ & $35.1 *$ & $4.7^{*}$ & $12.1 *$ & $7.9 *$ & $25.5 *$ & $43.3 *$ & 0.9 & 0.3 & Lat:Lon + D & 47.5 & \\
\hline $\ln N$ & $39.2 *$ & 3.5 & $12.3 *$ & $7.3^{*}$ & $25.9 *$ & $46.9 *$ & 1.9 & 0.9 & $\begin{array}{l}\text { (a) Lat:Lon + D + Y } \\
\text { (b) Lat:Lon + E }\end{array}$ & $\begin{array}{l}54.7 \\
53.8\end{array}$ & $0.77(<0.001)$ \\
\hline$N_{0}$ & $49.7 *$ & $8.5^{*}$ & $16.1 *$ & $15.9 *$ & $36.2 *$ & $57.2 *$ & 1.3 & 0.2 & Lat:Lon + D + Y & 64.6 & $1(<0.001)$ \\
\hline$N_{1}$ & $34.3 *$ & 5.6 & $9.3^{*}$ & $9.2^{*}$ & $24.3 *$ & $44.1 *$ & 1.0 & 0.1 & Lat:Lon + D & 48.7 & \\
\hline$N_{2}$ & $22.9 *$ & 7.8 & $6.8^{*}$ & $9.2 *$ & $17.1 *$ & $34.3 *$ & 0.6 & 0.0 & Lat:Lon + D & 39.1 & \\
\hline$L_{\text {mean }}$ & 4.8 & 2.7 & 5.1 & 2.7 & $8.1^{*}$ & $8.0^{*}$ & 0.0 & 5.0 & Lat:Lon & 8.0 & \\
\hline$L_{0.05}$ & $14.3^{*}$ & 6.6 & 3.1 & 0.1 & 4.1 & 5.1 & 3.2 & 2.6 & $\mathrm{D}+\mathrm{S}$ & 22.6 & \\
\hline$L_{0.95}$ & 0.0 & 1.6 & $36.4 *$ & 1.4 & $36.5^{*}$ & $81.2^{*}$ & 8.1 & $11.2^{*}$ & Lat:Lon & 81.2 & \\
\hline$L_{\max }$ & $12.8 *$ & 6.3 & $16.1 *$ & 1.1 & 0.0 & 2.5 & $4.9^{*}$ & $14.1 *$ & $\begin{array}{l}\text { (a) } \mathrm{D}+\mathrm{T}+\mathrm{E} \\
\text { (b) } D+T+Y\end{array}$ & $\begin{array}{l}40.4 \\
34.4\end{array}$ & $0.47(<0.001)$ \\
\hline \multicolumn{12}{|c|}{ B. Osteichthyes } \\
\hline $\ln B i$ & $28.4 *$ & 1.6 & $29.3 *$ & $13.2 *$ & $35^{*}$ & $50.9 *$ & $5.2^{*}$ & $6.8^{*}$ & $\begin{array}{l}\text { (a) Lat:Lon + E } \\
\text { (b) Lat:Lon + Y }\end{array}$ & $\begin{array}{l}56.1 \\
54.5\end{array}$ & $1(<0.001)$ \\
\hline $\ln N$ & $46.1 *$ & 1.4 & $37.7 *$ & $22.2 *$ & $44.4^{*}$ & $60 *$ & $6.8^{*}$ & 4.5 & Lat:Lon + D + Y & 68.8 & $0.90(<0.001)$ \\
\hline$N_{0}$ & $54.4 *$ & $5.3 *$ & $44.6^{*}$ & $19.6^{*}$ & $41.7 *$ & $66.3 *$ & $2.3^{*}$ & 0.4 & $\begin{array}{l}\text { (a) Lat:Lon + D + Y } \\
\text { (b) Lat:Lon }+D+E\end{array}$ & $\begin{array}{l}69.5 \\
69.0\end{array}$ & $1(<0.001)$ \\
\hline$N_{1}$ & $32.1 *$ & $12.1^{*}$ & $25.5^{*}$ & $14.8^{*}$ & $21.5^{*}$ & $57.4 *$ & 0.3 & 0.6 & Lat:Lon + D & 60.7 & \\
\hline$N_{2}$ & $23.9 *$ & $11.5^{*}$ & $20.1 *$ & $12.5^{*}$ & $20.1 *$ & $50.7 *$ & 0.4 & 0.5 & Lat:Lon + D & 52.8 & \\
\hline$L_{\text {mean }}$ & $71.2 *$ & 1.8 & $43.8 *$ & $22.3 *$ & $48.6^{*}$ & $73.9 *$ & 0.0 & 0.0 & Lat:Lon + D & 80.6 & \\
\hline$L_{0.05}$ & $13.0 *$ & 0.3 & 0.5 & $14.4^{*}$ & 6.7 & $39.9 *$ & 0.3 & 3.1 & Lat:Lon + D & 44.4 & \\
\hline$L_{0.95}$ & $62.8 *$ & 2.3 & $28 *$ & $30.9 *$ & $44^{*}$ & $72.4 *$ & 0.0 & 0.1 & Lat:Lon + D & 75.6 & \\
\hline$L_{\max }$ & $20.4 *$ & 0.9 & $11.5^{*}$ & $22.2 *$ & $18.3^{*}$ & $40.4^{*}$ & $4.2 *$ & 1.6 & $\begin{array}{l}\text { (a) Lat:Lon }+\mathrm{D}+\mathrm{Y} \\
\text { (b) Lat:Lon }+D+E\end{array}$ & $\begin{array}{l}47.1 \\
47.1\end{array}$ & $0.92(<0.001)$ \\
\hline \multicolumn{12}{|c|}{ C. Crustacea } \\
\hline $\ln B i$ & $32.7 *$ & $7.9^{*}$ & $21.5^{*}$ & $30.0 *$ & $31.3 *$ & $66.0 *$ & 2.5 & 0.3 & Lat:Lon + D + Y & 73.6 & $0(0.94)$ \\
\hline $\ln N$ & $31.7 *$ & $8.9 *$ & $18.4 *$ & $23.4 *$ & $23.5^{*}$ & $52.5^{*}$ & $4.8^{*}$ & 3.1 & $\begin{array}{l}\text { (a) Lat:Lon }+\mathrm{D}+\mathrm{Y} \\
\text { (b) Lat:Lon }+D+E\end{array}$ & $\begin{array}{l}62.6 \\
60.5\end{array}$ & $-0.25(<0.001)$ \\
\hline$N_{0}$ & $20.6^{*}$ & $5.2 *$ & $12.8 *$ & $12.9 *$ & $10.4 *$ & $30.8 *$ & $7.1^{*}$ & $4.0^{*}$ & $\begin{array}{l}\text { (a) Lat:Lon }+\mathrm{T}+\mathrm{D}+\mathrm{Y} \\
\text { (b) Lat:Lon }+T+D+E\end{array}$ & $\begin{array}{l}46.4 \\
43.1\end{array}$ & $-0.56(<0.001)$ \\
\hline$N_{1}$ & $15.7 *$ & $4.6^{*}$ & 0.2 & $5.5^{*}$ & 6.7 & $15.5^{*}$ & $7.6^{*}$ & 1.6 & Lat:Lon + D + Y & 31.0 & $-0.68(<0.001)$ \\
\hline$N_{2}$ & $18.6^{*}$ & $3.4^{*}$ & 0.0 & 5.8 & 1.9 & 11.3 & $4.2 *$ & 0.2 & $\mathrm{D}+\mathrm{S}$ & 20.2 & \\
\hline$L_{\text {mean }}$ & $38.9 *$ & 0.8 & $12.5^{*}$ & $20.1 *$ & $26.5^{*}$ & $47.3^{*}$ & $5.6^{*}$ & 4.0 & Lat:Lon + D + Y & 58.1 & $0.94(<0.001)$ \\
\hline$L_{0.05}$ & $20.0 *$ & 0.4 & $13.5^{*}$ & $3.6^{*}$ & $20.3 *$ & $25.4 *$ & $8.7 *$ & $4.5^{*}$ & Lat:Lon + D + Y & 39.7 & $0.89(<0.001)$ \\
\hline$L_{0.95}$ & $45.4^{*}$ & 0.2 & $13.5^{*}$ & $26.2 *$ & $30.8^{*}$ & $45.9^{*}$ & 2.0 & 4.5 & Lat:Lon + D + E & 63.9 & \\
\hline$L_{\max }$ & $39.3 *$ & 0.4 & $7.4^{*}$ & $25.5^{*}$ & $24.5^{*}$ & $54.7 *$ & 0.2 & 0.0 & Lat:Lon + D & 68.5 & \\
\hline \multicolumn{12}{|c|}{ D. Cephalopoda } \\
\hline $\ln B i$ & $64.0 *$ & $8.6^{*}$ & $45.7^{*}$ & $17.0 *$ & $46.2 *$ & $66.5^{*}$ & $2.1^{*}$ & 0.2 & Lat:Lon + D + Y & 73.1 & $0.85(<0.001)$ \\
\hline $\ln N$ & $77.4 *$ & $3.4^{*}$ & $58.2^{*}$ & $16.0 *$ & $60.6^{*}$ & $81.5^{*}$ & 0.2 & 0.0 & Lat:Lon $+\mathrm{T}+\mathrm{D}+\mathrm{Y}$ & 87.8 & $0.70(<0.001)$ \\
\hline$N_{0}$ & $64.0 *$ & $4.7^{*}$ & $36.8^{*}$ & $16.3^{*}$ & $40.8^{*}$ & $65.1^{*}$ & $2.1^{*}$ & 0.0 & Lat:Lon + D + Y & 71.8 & $0.82(<0.001)$ \\
\hline$N_{1}$ & $44.4 *$ & 6.4 & $19.3^{*}$ & $9.9^{*}$ & $29.1 *$ & $42.4^{*}$ & 0.4 & 0.2 & Lat:Lon + D & 48.4 & \\
\hline$N_{2}$ & $29.8^{*}$ & 6.7 & $7.4^{*}$ & 1.2 & $15.9 *$ & $29.0 *$ & 0.2 & 0.2 & $\mathrm{D}$ & 29.8 & \\
\hline$L_{\text {mean }}$ & $52.0^{*}$ & 1.2 & $9.2 *$ & $18.3^{*}$ & $13.6^{*}$ & $52.8^{*}$ & $5.1^{*}$ & 0.9 & $\begin{array}{l}\text { (a) Lat:Lon + D + Y } \\
\text { (b) Lat:Lon }+D+E\end{array}$ & $\begin{array}{l}64.8 \\
64.0\end{array}$ & $0.89(<0.001)$ \\
\hline$L_{0.05}$ & $39.5^{*}$ & 0.9 & $12 *$ & $16.6^{*}$ & $12.8^{*}$ & $50.3^{*}$ & $9.0^{*}$ & $3.5^{*}$ & $\begin{array}{l}\text { (a) Lat:Lon + D + Y } \\
\text { (b) Lat:Lon }+D+E\end{array}$ & $\begin{array}{l}72.4 \\
70.8\end{array}$ & $0.74(<0.001)$ \\
\hline$L_{0.95}$ & $51.6^{*}$ & 9.0 & $20.1 *$ & $24.6^{*}$ & $35.9 *$ & $57.8 *$ & $12.7 *$ & 8.5 & $\begin{array}{l}\text { (a) } D+E \\
\text { (b) } D+Y\end{array}$ & $\begin{array}{l}57.6 \\
55.3\end{array}$ & $0.98(<0.001)$ \\
\hline$L_{\max }$ & $21.0 *$ & 1.5 & 1.2 & $6.5^{*}$ & 4.6 & $28.9^{*}$ & 4.8 & 0.0 & Lat:Lon + D + Y & 36.4 & $0.68(<0.001)$ \\
\hline
\end{tabular}


Table 4. Directions of changes throughout the study period $(Y)$ and at high values of fishing effort $(E)$ of the metrics considered for the total community and for the four sub-communities, as revealed by GAM analysis. The effect of the best model with significant effect of $Y$ or $E$ was considered. $B i$ : biomass; $N$ : abundance; $N_{0}, N_{1}$ and $N_{2}$ : diversity indices from Hill's series; for definition of the remaining length metrics see text; NS: non-significant effect; *: significant effect but with no clear trend; ly: indicates that the direction of change refers only to the last years of the dataset.

\begin{tabular}{lcccccccccc}
\hline \multirow{2}{*}{ Metrics } & \multicolumn{2}{c}{ Total Community } & \multicolumn{2}{c}{ Chondrichthyes } & \multicolumn{2}{c}{ Osteichthyes } & \multicolumn{2}{c}{ Crustacea } & \multicolumn{2}{c}{ Cephalopoda } \\
\cline { 2 - 10 } & $Y$ & $E$ & $Y$ & $E$ & $Y$ & $E$ & $Y$ & $E$ & $Y$ & $E$ \\
\hline $\ln B i$ & $\nearrow$ & $*$ & $\mathrm{NS}$ & $\mathrm{NS}$ & $\nearrow$ & $*$ & $\nearrow \searrow$ & $*$ & $\nearrow$ & $\mathrm{NS}$ \\
$\ln N$ & $\nearrow$ & $*$ & $\nearrow$ & $\searrow$ & $\nearrow$ & $*$ & $\nearrow \searrow$ & $*$ & $\nearrow$ & $\mathrm{NS}$ \\
$N_{0}$ & $\nearrow$ & $\mathrm{NS}$ & $\nearrow$ & $\searrow$ & $\nearrow$ & $\searrow$ & $1 \mathrm{\searrow}$ & $*$ & $\nearrow$ & $\mathrm{NS}$ \\
$N_{1}$ & $\mathrm{NS}$ & $\mathrm{NS}$ & $\mathrm{NS}$ & $\mathrm{NS}$ & $\mathrm{NS}$ & $\searrow$ & $1 \mathrm{\searrow}$ & $\nearrow$ & $\mathrm{NS}$ & $\mathrm{NS}$ \\
$N_{2}$ & $\mathrm{NS}$ & $\mathrm{NS}$ & $\mathrm{NS}$ & $\mathrm{NS}$ & $\mathrm{NS}$ & $\searrow$ & $1 \mathrm{l} \searrow$ & $\mathrm{NS}$ & $\mathrm{NS}$ & $\mathrm{NS}$ \\
$L_{\text {mean }}$ & $\nearrow$ & $*$ & $\mathrm{NS}$ & $\mathrm{NS}$ & $\mathrm{NS}$ & $\mathrm{NS}$ & $\nearrow$ & $\mathrm{NS}$ & $\nearrow$ & $\searrow$ \\
$L_{0.05}$ & $\nearrow$ & $*$ & $\mathrm{NS}$ & $\mathrm{NS}$ & $\mathrm{NS}$ & $\mathrm{NS}$ & $\nearrow$ & $\searrow \rightarrow$ & $\nearrow$ & $\searrow$ \\
$L_{0.95}$ & $\mathrm{NS}$ & $\mathrm{NS}$ & $\mathrm{NS}$ & $\searrow$ & $\mathrm{NS}$ & $\mathrm{NS}$ & $\mathrm{NS}$ & $\searrow \rightarrow$ & $\nearrow$ & $*$ \\
$L_{\max }$ & $\nearrow$ & $\searrow$ & $\nearrow$ & $\searrow$ & $\nearrow$ & $\searrow$ & $\nearrow$ & $\mathrm{NS}$ & $\nearrow$ & $\mathrm{NS}$ \\
\hline
\end{tabular}

present but not so strong for Osteichthyes and Cephalopoda. In contrast, the Crustacean sub-community presented more complex responses, and often showed decreasing temporal trends and positive effect of increased fishing effort. $L_{\max }$, and to a lesser extent abundance and $N_{0}$, were the metrics that to which year and effort most often contributed significantly for sub-communities (Table 4). In contrast, $N_{1}$ and $N_{2}$, i.e., diversity indices, showed lesser changes with year and effort.

GAM analysis of the biomass and abundance indices of the selected species explained a large part of the deviance (45-90\%; Table 5). There is a strong depth effect for every species, with a peak in biomass (Fig. S7) and abundance (not shown as very similar to the effect on biomass) depending on species preferred habitat. Similarly, the effect of geographical factors was also species specific, with several species presenting high biomasses in areas previously identified as important for the total community and the four sub-communities (e.g., M. merluccius, $R$. clavata, L. depurator in the Patraikos Gulf; Fig. S7). Temporal trends and/or the effect of fishing proved significant for the biomass of six out of the ten species. For $H$. dactylopterus, a commercially important benthic deep sea fish species, the increase of fishing effort had a negative, almost linear, effect on its biomass (Fig. S7). S. smaris, a shallow water commercial species, presented a more complex effect with fishing effort, while the two crustaceans $P$. heterocarpus and $L$. depurator seemed to be favoured by high values of fishing effort. For the rest of the species, fishing effort was not included in the final selected models. Concerning temporal trends, increases in biomass were observed for three (H. dactylopterus, $M$. merluccius and S. smaris) out of the five bony fish species examined. Decreasing trends were observed for all three crustacean species considered, especially for $N$. norvegicus, since biomasses of $P$. heterocarpus and $L$. depurator increased during the first years and declined afterwards, presenting relatively weak negative correlations overall (Table 5, Fig. S7). Concerning the two elasmobranches examined, (S. blainville and $R$. clavata), only geographical and bathymetric factors were included in the selected models. Biomass of $S$. blainville and $R$. clavata peaked at 350 and $250 \mathrm{~m}$, respectively.

\section{Discussion}

Spatial and temporal patterns of population and community metrics of the E. Ionian Sea megafaunal communities were related to geographical, environmental and fishing factors. In general, Generalized Additive Models have proved powerful tools for examining the effect of such factors (e.g., Katsanevakis 2006; Tserpes et al. 2011). In our case, they were able to explain large part of the variability for several metrics across the total community, the four taxonomic sub-communities, and the ten selected populations, despite the inherent high noise characterizing bottom trawl surveys (Gaertner et al. 2005). Location, i.e., the interaction between latitude and longitude, and bottom depth were the factors with the highest explanatory power in the models of the majority of the subsets and metrics examined. Although, in some of the final models, either location or (more commonly) depth dropped out and when both were kept, their explanatory power was clearly not additive. This comes from the correlation between location and depth, in particular with a fixed station protocol, where the locations convey the depth information.

Depth is known as one of the most influential factors on the distribution, abundance (e.g., Macpherson 2003; Politou et al. 2003; Tserpes et al. 2011) and other population and community metrics (e.g., Moranta et al. 1998; Lorance et al. 2002). However, depth-related patterns are ecosystem specific, especially for biodiversity (e.g., Moranta et al. 1998; Lorance et al. 2002, Magnussen 2002) and, as also seen in our case, they further depend on the sub-communities examined (e.g., Colloca et al. 2003). The total megafaunal community and the sub-community of Osteichthyes present similar patterns in abundance, with high spatial and bathymetric fluctuations and local peaks, but generally decline in deeper waters. This similarity is mostly due to the dominance of finfish in the total community as these make up $74 \%$ of the total biomass in our study, underlining the interest of exploring sub-communities separately. Indeed, variant patterns were observed for the remaining categories, in line with previous studies in the area (Politou et al. 2003); the abundance of 
Table 5. GAMs for abundance and biomass of selected species of the E. Ionian Sea: deviance explained (\%) by each one of the explanatory variables when considered alone, and total deviance explained (\%) by the final selected model(s). Best models were selected based on the minimization of $A I C$ and corresponding $\triangle A I C$. Some additional ecologically interpretable models were selected and are indicated in italics. Bi: biomass; $N$ : abundance; $D$ : depth; $S$ : salinity; $T$ : temperature; Lon: longitude; Lat: latitude; $Y$ : year; $E$ : fishing effort; “:” denotes interaction, “*” indicates statistically significant effect $(p<0.05)$; (a) principal model; (b): additional model; $r$ : Pearson's correlation coefficient of year with the effect of year.

\begin{tabular}{|c|c|c|c|c|c|c|c|c|c|c|c|}
\hline \multirow{2}{*}{ Metrics } & \multicolumn{8}{|c|}{ Explanatory variables (deviance explained \%) } & \multicolumn{3}{|c|}{ Best model } \\
\hline & $D$ & $S$ & $T$ & Lat & Lon & Lat $*$ Lon & $Y$ & $E$ & variables & dev. expl. \% & $r(p$-value $)$ \\
\hline \multicolumn{12}{|c|}{ Pagellus bogaraveo } \\
\hline $\log (B i)$ & $48.8^{*}$ & 1.0 & $13.9 *$ & $21.8^{*}$ & $8.1^{*}$ & $60.8^{*}$ & 0.2 & 0.1 & Lat:Lon + D & 68.6 & \\
\hline $\log (N)$ & $45.4^{*}$ & 0.9 & $14.8^{*}$ & $18.2 *$ & $16.9^{*}$ & $57.4^{*}$ & 0.0 & 0.1 & Lat:Lon + D & 63.4 & \\
\hline \multicolumn{12}{|c|}{ Helicolenus dactylopterus } \\
\hline $\log (B i)$ & $67.2 *$ & $11.3^{*}$ & $17.3^{*}$ & $42.2^{*}$ & $19.4^{*}$ & $76.0^{*}$ & $1.8^{*}$ & 0.3 & $\begin{array}{l}\text { (a) Lat:Lon }+\mathrm{D}+\mathrm{Y} \\
\text { (b) Lat:Lon }+D+E\end{array}$ & $\begin{array}{l}90.1 \\
89.7\end{array}$ & $0.92(<0.001)$ \\
\hline $\log (N)$ & $74.1 *$ & $16.4^{*}$ & $21.8^{*}$ & $32.1 *$ & $33.6^{*}$ & $77.3^{*}$ & $1.7 *$ & 0.2 & $\begin{array}{l}\text { (a) Lat:Lon + D + E } \\
\text { (b) Lat:Lon + D + Y }\end{array}$ & $\begin{array}{l}89.5 \\
89.1\end{array}$ & $1(<0.001)$ \\
\hline \multicolumn{12}{|c|}{ Lepidorhombus boscii } \\
\hline $\log (B i)$ & $54.4^{*}$ & 7.4 & $15.7 *$ & $30.4^{*}$ & $41.7 *$ & $72.6^{*}$ & 0.6 & 0.1 & Lat:Lon + D & 77.7 & \\
\hline $\log (N)$ & $58.3^{*}$ & 7.7 & $16.8^{*}$ & $29.3^{*}$ & $41.5^{*}$ & $72.1 *$ & 0.4 & 0.0 & Lat:Lon + D & 76.8 & \\
\hline \multicolumn{12}{|c|}{ Merluccius merluccius } \\
\hline $\log (B i)$ & $20.7 *$ & $2.4^{*}$ & $2.6^{*}$ & $24.8 *$ & $19.8 *$ & $49.4 *$ & $5.8^{*}$ & 3.8 & Lat:Lon + D + Y & 60.9 & $0.94(<0.001)$ \\
\hline $\log (N)$ & $38.9 *$ & $1.9 *$ & $13.5^{*}$ & $22.6^{*}$ & $16.8^{*}$ & $57.1 *$ & $6.9^{*}$ & $5.0^{*}$ & Lat:Lon + D + Y & 67.1 & $0.95(<0.001)$ \\
\hline \multicolumn{12}{|c|}{ Spicara smaris } \\
\hline $\log (B i)$ & $31.6^{*}$ & $14.4^{*}$ & $11.2 *$ & $40.4^{*}$ & $38.4^{*}$ & $68.4^{*}$ & 1.5 & 0.0 & $\begin{array}{l}\text { (a) Lat:Lon + D + Y } \\
\text { (b) Lat:Lon + D + E }\end{array}$ & $\begin{array}{l}74.6 \\
75.0\end{array}$ & $1(<0.001)$ \\
\hline $\log (N)$ & $52.2^{*}$ & $17.5^{*}$ & $24.6^{*}$ & $37.7 *$ & $38.5^{*}$ & $71.3^{*}$ & 1.2 & 0.6 & $\begin{array}{l}\text { (a) Lat:Lon + D + Y } \\
\text { (b) Lat:Lon + D + E }\end{array}$ & $\begin{array}{l}79.0 \\
79.2\end{array}$ & $1(<0.001)$ \\
\hline \multicolumn{12}{|c|}{ Squalus blainville } \\
\hline $\log (B i)$ & $54.9 *$ & 7.7 & $13.8 *$ & $11.4 *$ & $36.7 *$ & $60.5^{*}$ & 0.0 & 0.5 & Lat:Lon+D & 67.4 & \\
\hline $\log (N)$ & $59.3^{*}$ & $8.4^{*}$ & $14.3^{*}$ & $9.3^{*}$ & $37.2^{*}$ & $64.4^{*}$ & 0.2 & 0.1 & Lat:Lon+D & 73.8 & \\
\hline \multicolumn{12}{|c|}{ Raja clavata } \\
\hline $\log (B i)$ & $24.5^{*}$ & 4.3 & $13.1^{*}$ & $10.9^{*}$ & $16.9 *$ & $43.5^{*}$ & 0.1 & 0.0 & Lat:Lon+D & 45.5 & \\
\hline $\log (N)$ & $33.5^{*}$ & $4.7 *$ & $13.9 *$ & $13.7 *$ & $18.8^{*}$ & $51.8^{*}$ & 1.1 & 0.3 & Lat:Lon+D & 58.7 & \\
\hline \multicolumn{12}{|c|}{ Nephrops norvegicus } \\
\hline $\log (B i)$ & $20.4 *$ & 0.9 & 9.7 & $14.2 *$ & $23.8^{*}$ & $43.3^{*}$ & 1.4 & 0.9 & Lat:Lon + D + Y & 47.5 & $-0.99(<0.001)$ \\
\hline $\log (N)$ & $23.0 *$ & 0.9 & $11.4^{*}$ & $17.2^{*}$ & $26.8^{*}$ & $48.5^{*}$ & 1.1 & 0.8 & Lat:Lon + D + Y & 54.1 & $-1(<0.001)$ \\
\hline \multicolumn{12}{|c|}{ Plesionika heterocarpus } \\
\hline $\log (B i)$ & $45.0 *$ & 7.5 & $13.1^{*}$ & $19.8^{*}$ & $33.2^{*}$ & $58.5^{*}$ & 3.6 & 0.8 & $\begin{array}{l}\text { (a) Lat:Lon + D + Y } \\
\text { (b) Lat:Lon }+D+E\end{array}$ & $\begin{array}{l}63.2 \\
61.6\end{array}$ & $-0.22(<0.001)$ \\
\hline $\log (N)$ & $52.0^{*}$ & $10.6^{*}$ & $15.7 *$ & $21.2^{*}$ & $33.4^{*}$ & $62.5^{*}$ & 3.5 & 0.8 & Lat:Lon + D + Y & 67.6 & $-0.27(<0.001)$ \\
\hline \multicolumn{12}{|c|}{ Liocarcinus depurator } \\
\hline $\log (B i)$ & $36.3 *$ & $9.1 *$ & $11.5^{*}$ & $15.1 *$ & $25.9^{*}$ & $54.7 *$ & $4.5^{*}$ & $3.8^{*}$ & $\begin{array}{l}\text { (a) Lat:Lon + D + T + Y } \\
\text { (b) Lat:Lon + D + T + E }\end{array}$ & $\begin{array}{l}63.3 \\
62.5\end{array}$ & $-0.68(<0.001)$ \\
\hline $\log (N)$ & $36.8^{*}$ & $9.1 *$ & $12.3^{*}$ & $15.0 *$ & $26.7 *$ & $55.6^{*}$ & $4.4^{*}$ & $3.8^{*}$ & $\begin{array}{l}\text { (a) Lat:Lon }+\mathrm{D}+\mathrm{T}+\mathrm{Y} \\
\text { (b) Lat:Lon }+\mathrm{D}+\mathrm{T}+\mathrm{E}\end{array}$ & $\begin{array}{l}64.1 \\
63.5\end{array}$ & $-0.65(<0.001)$ \\
\hline
\end{tabular}


Osteichthyes and Cephalopods decreased with depth, whereas those of Chondrichthyes and of Crustaceans increased, especially below $200 \mathrm{~m}$. Such results may prove important for spatial management of selected sub-communities or species. The upper slope $250-700 \mathrm{~m}$ appeared to be the habitat with the highest biomass for Chondrichthyes. It is noteworthy that three of the shark species recorded at these depths are categorized as vulnerable in the IUCN (2012) red list, i.e. Oxynotus centrina, Squalus acanthias and Centrophorus granulosus, and one more (Galeorhinus galeus) even though recorded at shallow waters is also known to occur on the upper slope. Thus, maintaining biological diversity may require management of the fishing mortality of these vulnerable species in this depth zone. Moreover, spatial variation in $L_{0.05}$ can be used to identify nursery grounds: for Osteichthyes, low $L_{0.05}$ was obvious at around $200 \mathrm{~m}$ depth, reflecting the high proportions of juvenile fish, mainly Merluccius merluccius, in this depth zone, in line with previous studies (Tserpes et al. 2008). In addition, $L_{\max }$ increased with depth for all sub-communities, as did $L_{\text {mean }}$ and $L_{0.095}$ except for Chondrichthyes. These patterns suggest that the deeper-bigger pattern known at species level (Macpherson and Duarte 1991) exists for wider taxonomic groups, as mentioned by previous authors (e.g., Papiol et al. 2012), although not for the overall community, at least to $800 \mathrm{~m}$ (Stefanescu et al. 1992).

Furthermore, spatial patterns or variations are common across ecosystems (Magnussen 2002; Macpherson 2003; Gaertner et al. 2005; Sousa et al. 2006) and were also identified in our study in the E. Ionian Sea. For example, local peaks of biomass and abundance for the whole community and several taxa (e.g., Chondrichthyes, Osteichthyes, M. merluccius, Raja clavata) were observed in coordinates corresponding to the Patraikos Gulf (approximately 38.3N/21.5E; Fig. 1), probably reflecting the relatively high productivity of this area (Ramfos et al. 2006) explained by the presence of river deltas and estuaries. As concerns diversities of the total community, other than the Patraikos Gulf, these were also maximized in areas east of the central E. Ionian Sea islands, probably owing to increased diversities of the Crustacean sub-community. These patterns are probably related to habitat preferences of the species/community and reflect the synergistic effect of other environmental factors, some of which (e.g., productivity, currents, substrate) may not have been included in the analysis.

Despite this, the remaining environmental factors examined, even though significant in many cases when considered alone (especially bottom temperature), were seldom included in the final selected models for the metrics considered. Temperature is correlated with depth, so when depth was included in the final models, the additional contribution of temperature was not significant. Furthermore, it seems that due to the relatively stable thermal conditions observed below $100 \mathrm{~m}$ depth in the study area, temperature may play only a secondary role in explaining patterns in community distribution in deeper waters, at least to the community level. Concerning salinity, its non-inclusion in the final models may be due to the narrow range of the majority of records, which results in minor effects on the communities/species. Furthermore, spatial factors and bathymetry additionally act as proxies for salinity and temperature, at least to certain extent, and this is also true for several other environmental factors. In this context, even though some of the parameters included in the GAMs may be well related to community distributions, they may not reveal direct cause-and-effect information but may integrate the effect of other environmental variables such as water mass characteristics, productivity and food availability, which are known to affect spatial and bathymetric patterns (e.g., Papiol et al. 2012; Abelló et al. 1988). Nevertheless, a certain part of the variability was not explained by the factors considered in the analysis, and including additional environmental parameters (e.g., substrate type, Katsanevakis et al. 2009) would probably increase the explanatory power of the models, if available.

On the contrary, either the year or the fishing effort were often significant and were included in the final selected models, despite being rarely significant when considered alone, especially fishing effort. GAMs were effective in detecting non-linear temporal trends and effects of fishing pressure after testing for spatial and bathymetric factors. Specifically, the term Year was almost always included in the final models when it showed significant effect when considered alone, while it was additionally included in the final models for 13 metrics (total community: $N_{0}, L_{\text {mean }}, L_{0.05}, L_{\max }$; Chondrichthyes: abundance, $N_{0}$; cephalopods: abundance, $L_{\max }$; Spicara smaris: biomass, abundance; Nephrops norvegicus: biomass, abundance; $P$. heterocarpus: abundance) despite not being significant as a single term. Even though long time series (few decades) are usually required to detect population and community changes related to changes in fishing practices, several studies have revealed effects of fishing in shorter periods ( $<10$ years, e.g., Bianchi et al. 2000). In our case, GAMs revealed responses to fishing despite the examined time series being relatively short. The metrics were better related to temporal trends than to fishing effort. Effort is difficult to measure and absolute values of fishery statistics may not be complete or fully reliable, especially in a multi-gear fishery like that in the E. Ionian Sea. Thus, although clearly not causal, time (year) might be a better reflection of the (cumulative) change in fishing pressure. An increase in most of the examined metrics was observed throughout the study period, with the exception of abundance indices and diversities for the Crustaceans sub-community and species examined, which declined especially during the most recent years. Since the effect of fishing effort was negative for several of the metrics, we assume that the declining fishing effort of the Greek fishing fleet (Fig. 2) has contributed to the observed increase in biomass, abundance, species richness and some of the length-related metrics. However, one cannot ignore the possible contribution of other processes which may favour ecosystem productivity resulting in bottom-up effects (Rochet et al. 2010) and/or recruitment success. These may include (i) anthropogenic activities (e.g., aquaculture; Machias et al. 2006), (ii) changes in climatic indices such as the North Atlantic Oscillation index, which has been shown to affect species abundance and distribution, including those of deep-sea species (e.g., Cartes et al. 2009) at least to the population level, and (iii) hydrological changes (e.g., changes in water mass: Souvermezoglou and Krasakopoulou 2005; Bensi et al. 2013). Even though we have not detected a temporal trend in temperature and salinity 
in our dataset, we cannot exclude e.g., changes in the centre of gravity of the distribution of some deep-sea species, or other responses. Thus, possible links with climatic changes and the mechanisms involved, remain to be examined.

The effect of fishing was found to linearly affect abundance and $N_{0}$ of Chondrichthyes, which are more sensitive to fishing pressure (Stevens et al. 2000; ICES 2005) suggesting that this sub-community can be used as an indicator for the effects of fishing on the study ecosystem. This was also the case for Helicolenus dactylopterus, which declined linearly with increasing fishing effort. $H$. dactylopterus is a benthic species, sensitive because of its low growth rate, low fecundity and the distribution of juveniles in areas of intensive fishing activity (D'Onghia et al. 1996; Mytilineou et al. 2006; Sequeira et al. 2009), and important effects of fishing for this species have also been identified in the Central Mediterranean (Dimech et al. 2012). In the North Sea, $R$. clavata has been proposed as an indicator species for which reference points of overexploitation of the community could be defined (ICES 2005). However, in our study, its abundance was not found to respond to fishing effort nor to vary with time over the studied period (where effort decreased); nor did Squalus blainville the other Chondrichthyes analysed as a single species. Possibly a longer time series is required to reveal changes in the abundance of these long-lived species. Our results highlight that species with different life history traits respond to fishing pressure in different ways; Chondrichthyes which are generally longlived species are negatively related to fishing effort whereas some short-lived decapods respond positively and can recover rapidly in abundance and biomass. Specifically, two of the crustacean species considered, Plesionika heterocarpus and Liocarcinus depurator, seemed to increase in abundance and biomass at high values of fishing effort. This may be caused by indirect trophic effects caused by the removal of their predators (e.g., large fish and octopuses) by fishing, i.e., the predation mortality of these crustaceans would be relaxed at high fishing effort. In addition, since these species are partly scavengers, the positive effects may also be related to a direct increase of food supply from (i) discards and (ii) "non-catch" mortality of benthos in the towpath of the fishing gear (e.g., Catchpole et al. 2006). More complex effects were observed for the whole crustacean sub-community, possibly because of both trophic and fisheries effects, as crustaceans include targeted and noncommercial species with a great diversity of feeding strategies, from scavengers (e.g., L. depurator) to small particulate feeders (e.g., P. heterocarpus) (Bozzano and Sardà 2002; Cartes et al. 2002). An additional factor contributing to these effects is that a considerable fraction (27\%) of the crustacean landings in the area are caught by trawlers (Anon. 2008), the effort of which did not significantly decline during the survey period. It is also worth noting that after 2003 Italian trawlers started targeting deep-sea shrimps in the E. Ionian Sea (Mytilineou and Machias 2007), which may further reflect the decline of $N$. norvegicus during this period. Therefore, monitoring different sub-communities and species may improve appraisals of the effect of fishing, which may be masked in metrics for the whole community because of contrasting life history traits, trophic position and different fishing techniques. Our findings allow us to suggest that a combination of the trends observed in the abundance of severely affected by fisheries, long-lived and/or low growth rate species (e.g., Chondrichthyes as a group and H. dactylopterus) and of some short-lived decapod crustaceans (e.g., P. heterocarpus) which proliferate from fishing, may be used in management as indicators of the effect of fishing on the deep-sea resources.

The metrics examined here showed variable sensitivity to fisheries and/or time. Such effects were more common on abundance indices, the number of species $\left(N_{0}\right)$ and some of the length metrics, especially the one related to the lengths of the larger individuals, i.e. $L_{\max }$. The reduction of abundance indices and $N_{0}$ caused by increased fishing pressure reflects the direct removal of targeted and non-targeted catch. Specifically, a reduction of species richness at high values of fishing effort does not necessarily imply local extinction of populations, but is in line with the decreased abundance which further decreases the probability of a species to be caught within a sample. However, the improving sorting ability of the personnel on-board scientific survey as years go by cannot be excluded as a possible bias that may have affected the documented increase of species richness during the survey period. Regarding length metrics, the negative effect of high values of fishing effort on large individuals is related to (i) the increased mortality in populations, so that a lower proportion of individuals reach old age and large size (Shin et al. 2005) and (ii) possible evolutionary effects such as selection of early reproduction (Law 2000).

The present study suggests that the E. Ionian Sea megafaunal assemblages have improved during the study period in line with recent stock assessments in the area which report recovery of previously overexploited stocks. Specifically, based on F/Fmsy and B/Bmsy (F: fishing mortality; B: stock biomass; msy: maximum sustainable yield), it has been shown that the stock biomasses of Spicara smaris, S. flexuosa, Mullus barbatus, M. surmuletus and Merluccius merluccius have increased (Anon. 2012; STECF 2012). Our approach underlines that keeping fishing effort at an appropriate overall level may have measurable ecological effects within a short time frame. The currently decreasing trend of fishing effort is mainly an outcome of the decline in the number of fishing vessels, particularly of small scale fisheries, during the study period (Anon. 2008). This seems to substantially contribute to the goal of achieving good environmental status as defined by the Marine Strategy Framework Directive (MSFD) (EU 2010). In particular, biomass, abundance and several size-based indicators, which are related to descriptors 1 (biological diversity) and 3 (exploited species) of the MSFD have increased for the total community as well as for Chondrichthyes, Osteichthyes, Cephalopods and several commercial species. In other words, the improvement of the state of the community seems to involve several taxonomic groups including those sensitive to fishing, e.g., Chondrichthyes (Stevens et al. 2000), as well as fast growing ones e.g., Cephalopods (Caddy and Rodhouse 1998). The observed changes may or may not be sufficient to achieve the overarching goals of e.g., exploiting commercial species at levels capable of producing MSY and maintaining biological diversity. In terms of management, keeping effort at an appropriate level does not explicitly imply effort regulation, and a number of other management tools have been used 
to this end (e.g., Worm et al. 2009; Colloca et al. 2013). In the East Ionian Sea, we found strong spatial patterns in fish, crustacean and cephalopod distributions, so that reducing the fishing mortality of a particular population or sub-community might be achievable by setting fishing restrictions in the area where the populations or community is most abundant. In this framework, the metrics used here might allow the identification of the preferred habitats of species and sub-communities and allow management measures to be taken. Finally, taking into account a possible fishing effort reallocation towards deeper waters resulting from EU regulation 1967/2006 (which prohibits trawling within 1.5 nautical mile of the coast and thus reduces available coastal fishing grounds; Tserpes et al. 2011) as well as the increasing interest for deep-sea resources (Mytilineou and Machias 2007), the above results could be useful in designing management plans, particularly under the concept of an ecosystem approach.

Acknowledgements. This study was financed by the DEEPFISHMAN project (European Community's FP7, Grant No. 227390). Cofinancing was provided to HCMR from the Greek General Secretariat for Research and Technology. We wish to thank the editor and three anonymous referees for constructive comments and suggestions that greatly helped to improve the manuscript.

\section{Electronic supplementary materials}

Figure S1: Annual box-plots for biomass and abundance indices and mean length for the four sub-communities examined. Figure S2: Annual means and standard errors of biomass and abundance indices and mean length of the ten species examined.

Figures S3-S7: Estimated smooth terms of the parameters contributing to the selected GAMs for metrics of the four subcommunities and ten species examined.

\section{References}

Abelló P., Valladares F.J., Castellón A., 1988, Analysis of the structure of decapod crustacean assemblages off the Catalan coast (North-West Mediterranean). Mar. Biol. 98, 39-49.

Anonymous, 2001, Patterns and propensities in Greek fishing effort and catches. Report to the EU (DGXIV), project 00/018.

Anonymous, 2008, National Program for the Collection of Fisheries Data (2007-2008). Athens, Greece, Fisheries Research Institute and Hellenic Center for Marine Research. Technical Report (EC $1543 / 2000)$.

Anonymous, 2012, Management plan for the Greek bottom trawlers. Final report.

Bensi M., Rubino A., Cardin V., Hainbucher D., Mancero-Mosquera I., 2013, Structure and variability of the abyssal water masses in the Ionian Sea in the period 2003-2010. J. Geophys. Res. Oceans 118, 931-943.

Bertrand J.A., De Sola L.G., Papaconstantinou C., Relini G., Souplet A., 2002a, The general specifications of the MEDITS surveys. Sci. Mar. 66, 9-17.

Bertrand J.A., Leonori I., Dremière P.-Y., Cosimi G., 2002b, Depth trajectory and performance of a trawl used for an international bottom trawl survey in the Mediterranean. Sci. Mar. 66, 169-182.
Bianchi G., Gislason H., Graham K., Hill L., Jin X., Koranteng K., Manickchand-Heileman S., Paya I., Sainsbury K., Sanchez F., Zwanenburg K., 2000, Impact of fishing on size composition and diversity of demersal fish communities. ICES J. Mar. Sci. 57, 558-571.

Bozzano A., Sardà F., 2002, Fishery discard consumption rate and scavenging activity in the northwestern Mediterranean Sea. ICES J. Mar. Sci. 59, 15-28.

Burnham K.P., Anderson D.R., 2002, Model selection and multimodel inference: a practical information-theoretic approach. 2nd edition, Springer, New York.

Caddy J.F., Rodhouse P.G., 1998, Cephalopod and groundfish landings: evidence for ecological change in global fisheries? Rev. Fish Biol. Fish. 8, 431-444.

Campbell N., Neat F., Burns F., Kunzlik P., 2011, Species richness, taxonomic diversity, and taxonomic distinctness of the deepwater demersal fish community on the Northeast Atlantic continental slope (ICES Subdivision VIa). ICES J. Mar. Sci. 68, 365376.

Cartes J.E., Abelló P., Lloris D., Carbonell A., Torres P., Maynou F., Gil de Sola L., 2002, Feeding guilds of western Mediterranean demersal fish and crustaceans: an analysis based on a spring survey. Sci. Mar. 66, 209-220.

Cartes J.E., Maynou F., Fanelli E., Papiol V., Lloris D., 2009, Long-term changes in the composition and diversity of deepslope megabenthos and trophic webs off Catalonia (western Mediterranean): Are trends related to climatic oscillations? Prog. Oceanogr. 82, 32-46.

Catchpole T.L., Frid C.L.J., Gray T.S., 2006, Importance of discards from the English Nephrops norvegicus fishery in the North Sea to marine scavengers. Mar. Ecol. Prog. Ser. 313, 215-226.

Clarke K.R., Warwick R.M., 1994, Change in marine communities: an approach to statistical analysis and interpretation. Plymouth, UK, Natural Environment Research Council.

Colloca F., Cardinale M., Belluscio A., Ardizzone G., 2003, Pattern of distribution and diversity of demersal assemblages in the central Mediterranean Sea. Estuar. Coast. Shelf Sci. 56, 469-480.

Colloca F., Cardinale M., Maynou F., Giannoulaki M., Scarcella G., Jenko K., Bellido J.M., Fiorentino F., 2013, Rebuilding Mediterranean fisheries: a new paradigm for ecological sustainability. Fish Fish. 14, 89-109.

Cury P.M., Christensen V., 2005, Quantitative Ecosystem Indicators for Fisheries Management. ICES J. Mar. Sci. 62, 307-310.

D’Onghia G., Mastrototaro F., Panza M., 1996, On the growth and mortality of rockfish, Helicolenus dactylopterus (Delaroche 1809), from the Ionian Sea. FAO Fish. Rep. 533, 143-152.

D’Onghia G., Politou C.Y., Bozzano A., Lloris D., Rotllant G., Sion L., Mastrototaro F., 2004, Deep-water fish assemblages in the Mediterranean Sea. Sci. Mar. 68, 87-99.

Dimech M., Camiller M., Hiddink J.G., Kaiser M.J., Ragonese S., Schembri P.J., 2008, Differences in demersal community structure and biomass size spectra within and outside the Maltese Fishery Management Zone (FMZ). Sci. Mar. 72, 669-682.

Dimech M., Kaiser M.J., Ragonese S., Schembri P.J., 2012, Ecosystem effects of fishing on the continental slope in the Central Mediterranean Sea. Mar. Ecol. Prog. Ser. 449, 41-54.

EU, 2010, Comission Decision on criteria and methodological standards on good environmental status of marine waters 2010/477/EU, Official J. Eur. Union.

Gaertner J.-C., Bertrand J.A., Sola L.G.d., Durbec J.-P., Ferrandis E., Souplet A., 2005, Large spatial scale variation of demersal fish assemblage structure on the continental shelf of the NW Mediterranean Sea. Mar. Ecol. Prog. Ser. 297, 245-257. 
Gordon J.D.M., Bergstad O.A., 1992, Species composition of demersal fish in the Rockall Trough, north-eastern Atlantic, as determined by different trawls. J. Mar. Biol. Assoc. UK 72, 213-230.

Greenstreet S.P., Hall S.J., 1996, Fishing and the ground-fish assemblage structure in the North-Western North Sea: an analysis of long-term and spatial trends. J. Anim. Ecol. 65, 577-598.

Greenstreet S.P.R., Rogers S.I., 2006, Indicators of the health of the North Sea fish community: identifying reference levels for an ecosystem approach to management. ICES J. Mar. Sci. 63, 573593.

Hill M.O., 1973, Diversity and evenness: a unifying notation and its consequences. Ecology 54, 427-432.

ICES, 2005, Ecosystem Effects of Fishing: Impacts, Metrics and Management Strategies. ICES Coop. Res. Rep. 272.

IUCN, 2012, IUCN Red List of Threatened Species. Version 2012.1. www.iucnredlist.org.

Jennings S., 2005, Indicators to support an ecosystem approach to fisheries. Fish Fish. 6, 212-232.

Johnson A.F., Jenkins S.R., Hiddink J.G., Hinz H., 2013, Linking temperate demersal fish species to habitat: scales, patterns and future directions. Fish Fish. 14, 256-280.

Katsanevakis S., 2006, Modelling fish growth: Model selection, multi-model inference and model selection uncertainty. Fish. Res. 81, 229-235.

Katsanevakis S., Maravelias C.D., Damalas D., Karageorgis A.P., Tsitsika E.V., Anagnostou C., Papaconstantinou C., 2009, Spatiotemporal distribution and habitat use of commercial demersal species in the eastern Mediterranean Sea. Fish. Oceanogr. 18, 439-457.

Koslow A.J., 1993, Community structure in North Atlantic deep-sea fishes. Prog. Oceanogr. 31, 321-338.

Koslow J.A., Boehlert G.W., Gordon J.D.M., Haedrich R.L., Lorance P., Parin N., 2000, Continental slope and deep-sea fisheries: implications for a fragile ecosystem. ICES J. Mar. Sci. 57, 548-557.

Labropoulou M., 2007, European Commission Data collection regulation (EC 1543/2000). In: Papaconstantinou C., Zenetos A., Vassilopoulou V., Tserpes G. (Eds.) State of Hellenic fisheries. HCMR Publ., Athens, pp. 159-165.

Law R., 2000, Fishing, selection, and phenotypic evolution. ICES J. Mar. Sci. 57, 659-668.

Lorance P., Souissi S., Uiblein F., 2002, Point, alpha and beta diversity of carnivorous fish along a depth gradient. Aquat. Living Res. 15, 263-271.

Machias A., Vasilopoulou V., Vatsos D., Bekas P., Kallianotis A., Papaconstantinou C., Tsimenides N., 2001, Bottom trawl discards in the northeastern Mediterranean Sea. Fish. Res. 53, 181195.

Machias A., Giannoulaki M., Somarakis S., Maravelias C.D., Neofitou C., Koutsoubas D., Papadopoulou K.N., Karakassis I., 2006, Fish farming effects on local fisheries landings in oligotrophic seas. Aquaculture 261, 809-816.

Macpherson E., 2003, Species range size distributions for some marine taxa in the Atlantic Ocean. Effect of latitude and depth. Biol. J. Linn. Soc. 80, 437-455.

Macpherson E., Duarte C.M., 1991, Bathymetric trends in demersal fish size: is there a general relationship? Mar. Ecol. Prog. Ser. 71, 103-112.

Magnussen E., 2002, Demersal fish assemblages of Faroe Bank: species composition, distribution, biomass spectrum and diversity. Mar. Ecol. Prog. Ser. 238, 211-225.

Moranta J., Stefanescu C., Massutí E., Morales-Nin B., Lloris D., 1998, Fish community structure and depth-related trends on the continental slope of the Balearic Islands (Algerian basin, western Mediterranean). Mar. Ecol. Prog. Ser. 171, 247-259.
Mytilineou C., Kavadas S., Politou C.Y., Kapiris K., Tursi A., Maiorano P., 2006, Catch composition in red shrimp (Aristaeomorpha foliacea and Aristeus antennatus) grounds in the eastern Ionian Sea. Hydrobiologia 557, 255-160.

Mytilineou C., Machias A., 2007, Deep-water fisheries resources in the Hellenic Seas. In: Papaconstantinou C., Zenetos A., Vassilopoulou V., Tserpes G. (Eds.) State of Hellenic Fisheries. HCMR Publ., Athens, pp. 213-222.

Papiol V., Cartes J.E., Fanelli E., Maynou F., 2012, Influence of environmental variables on the spatio-temporal dynamics of benthopelagic assemblages in the middle slope of the Balearic Basin (NW Mediterranean). Deep-Sea Res. Part I 61, 84-99.

Politou C.-Y., 2007, Current state of demersal fisheries resources. In: Papaconstantinou C., Zenetos A., Vassilopoulou V., Tserpes G. (Eds.) State of Hellenic fisheries. HCMR Publ., Athens, pp. 183191.

Politou C.Y., Mytilineou C., D’Onghia G., Dokos J., 2008a, Demersal faunal assemblages in the deep waters of the eastern Ionian Sea. J. Nat. Hist. 42, 661-672.

Politou C.-Y., Tserpes G., Dokos J., 2008b, Identification of deepwater pink shrimp abundance distribution patterns and nursery grounds in the eastern Mediterranean by means of generalized additive modelling. Hydrobiologia 612, 99-107.

Politou C.Y., Kavadas S., Mytilineou C., Tursi A., Carlucci R., Lembo G., 2003, Fisheries resources in the deep waters of the eastern Mediterranean (Greek Ionian Sea). J. Northw. Atl. Fish. Sci. 31, $35-46$.

Ramfos A., Isari S., Somarakis S., Georgopoulos D., Koutsikopoulos C., Fragopoulu N., 2006, Mesozooplankton community structure in offshore and coastal waters of the Ionian Sea (eastern Mediterranean) during mixed and stratified conditions. Mar. Biol. $150,29-44$.

Rice J., 2003, Environmental health indicators. Ocean Coast. Manage. 46, 235-259.

Rice J.C., 2000, Evaluating fishery impacts using metrics of community structure. ICES J. Mar. Sci. 57, 682-688.

Rochet M.-J., Trenkel V.M., 2003, Which community indicators can measure the impact of fishing? A review and proposals. Can. J. Fish. Aquat. Sci. 60, 86-99.

Rochet M.-J., Trenkel V.M., Carpentier A., Coppin F., De Sola L.G., Léauté J.-P., Mahé J.-C., Maiorano P., Mannini A., Murenu M., Piet G., Politou C.-Y., Reale B., Spedicato M.-T., Tserpes G., Bertrand J.A., 2010, Do changes in environmental and fishing pressures impact marine communities? An empirical assessment. J. Appl. Ecol. 47, 741-750.

Rogers S.I., Maxwell D., Rijnsdorp A.D., Damm U., Vanhee W., 1999, Fishing effects in northeast Atlantic shelf seas: patterns in fishing effort, diversity and community structure. IV. Can comparisons of species diversity be used to assess human impacts on demersal fish faunas? Fish. Res. 40, 135-152.

Sequeira V., Neves A., Vieira A.R., Figueiredo I., Gordo L.S., 2009, Age and growth of bluemouth, Helicolenus dactylopterus, from the Portuguese continental slope. ICES J. Mar. Sci. 66, 524-531.

Shin Y.-J., Rochet M.J., Jennings S., Field J.C., Gislason H., 2005, Using size-based indicators to evaluate the ecosystem effects of fishing. ICES J. Mar. Sci. 62, 384-396.

Siokou-Frangou I., Christaki U., Mazzocchi M.G., Montresor M., d'Alcala M.R., Vaque D., Zingone A., 2010, Plankton in the open Mediterranean Sea: a review. Biogeosciences 7, 1543-1586.

Sousa P., Azevedo M., Gomes M.C., 2006, Species-richness patterns in space, depth, and time (1989-1999) of the Portuguese fauna sampled by bottom trawl. Aquat. Living Res. 19, 93-103. 
Souvermezoglou A., Krasakopoulou E., 2005, Nutrients in deep seas. In: Papathanasiou E., Zenetos A. (Eds.) State of the Hellenic Marine environment. HCMR Publ., Athens, pp. 137-144.

STECF, 2012, Report of the Scientific, Technical and Economic Committee for Fisheries (STECF) on assessment of Merluccius merluccius, Mullus barbatus, Mullus surmuletus, Boops boops, Spicara smaris/Spicara flexuosa and Nephrops norvegicus in Aegean and Ionian waters (STECF 12-21). Publications Office of the European Union, Luxembourg. Joint Research centre Scientific and Policy reports.

Stefanescu C., Rucabado J., Lloris D., 1992, Depth-size trends in western Mediterranean demersal deep-sea fishes. Mar. Ecol. Prog. Ser. 81, 205-213.

Stevens J.D., Bonfil R., Dulvy N.K., Walker P.A., 2000, The effects of fishing on sharks, rays, and chimaeras (chondrichthyans), and the implications for marine ecosystems. ICES J. Mar. Sci. 57, 476494.

Theocharis A., Georgopoulos D., Lascaratos A., Nittis K., 1993, Water masses and circulation in the central region of the Eastern Mediterranean: Eastern Ionian, South Aegean and Northwest Levantine, 1986-1987. Deep-Sea Res. Part II 40, 1121-1142.
Thessalou-Legaki M., 2007, Decapod crustaceans: an account on species occurrence and exploitation in Hellenic waters. In: Papaconstantinou C., Zenetos A., Vassilopoulou V., Tserpes G. (Eds.) State of Hellenic fisheries. HCMR Publ., Athens, pp. 8592.

Tserpes G., Politou C.-Y., Peristeraki P., Kallianiotis A., Papaconstantinou C., 2008, Identification of hake distribution pattern and nursery grounds in the Hellenic seas by means of generalized additive models. Hydrobiologia 612, 125-133.

Tserpes G., Tzanatos E., Peristeraki P., 2011, Spatial management of the Mediterranean bottom-trawl fisheries: the case of the southern Aegean Sea. Hydrobiologia 670, 267-274.

Wood S.N., 2006, Generalized Additive Models. An Introduction with R. Chapman \& Hall, London.

Worm B., Hilborn R., Baum J.K., Branch T.A., Collie J.S., Costello C., Fogarty M.J., Fulton E.A., Hutchings J.A., Jennings S., Jensen O.P., Lotze H.K., Mace P.M., McClanahan T.R., Minto C., Palumbi S.R., Parma A.M., Ricard D., Rosenberg A.A., Watson R., Zeller D., 2009, Rebuilding Global Fisheries. Science 325, 578-585. 


\section{Annexes: Lists of species included in the analysis}

Table A1. List of Osteichthyes species included in the analysis.

\begin{tabular}{|c|c|c|}
\hline Acantholabrus palloni & Epigonus denticulatus & Pagrus pagrus \\
\hline Argentina sphyraena & Epigonus telescopus & Paralepis speciosa \\
\hline Arnoglossus imperialis & Epinephelus aeneus & Peristedion cataphractum \\
\hline Arnoglossus kessleri & Epinephelus guaza & Phycis blennoides \\
\hline Arnoglossus laterna & Eutrigla gurnardus & Phycis phycis \\
\hline Arnoglossus rueppelli & Gadella maraldi & Psetta maxima \\
\hline Arnoglossus thori & Gadiculus argenteus & Scophthalmus rhombus \\
\hline Aspitrigla cuculus & Gaidropsarus mediterraneus & Scorpaena elongata \\
\hline Aspitrigla obscura & Gaidropsarus spp. & Scorpaena notata \\
\hline Aulopus filamentosus & Gnathophis mystax & Scorpaena porcus \\
\hline Bellotia apoda & Gobius niger & Scorpaena scrofa \\
\hline Benthocometes robustus & Gobius paganellus & Scorpaena sp. \\
\hline Benthosema glaciale & Gobius spp. & Serranus cabrilla \\
\hline Blenniidae & Helicolenus dactylopterus & Serranus hepatus \\
\hline Blennius ocellaris & Hoplostethus mediterraneus & Solea impar \\
\hline Boops boops & Hymenocephalus italicus & Solea kleini \\
\hline Bothus podas & Lepidopus caudatus & Solea spp. \\
\hline Callanthias ruber & Lepidorhombus boscii & Solea vulgaris \\
\hline Callionymus lyra & Lepidorhombus whiffiagonis & Sparus aurata \\
\hline Callionymus maculatus & Lepidotrigla cavillone & Sphoeroides cutaneus \\
\hline Callionymus risso & Lepidotrigla dieuzeidei & Spicara flexиosa \\
\hline Callionymus spp. & Leusueurigobius friesii & Spicara maena \\
\hline Capros aper & Lophius budegassa & Spicara smaris \\
\hline Caranx rhonchus & Lophius piscatorius & Stomias boa \\
\hline Carapus acus & Macrorhamphosus scolopax & Symbolophorus veranyi \\
\hline Centracanthus cirrus & Merlangius merlangus & Symphodus spp. \\
\hline Centrolophus niger & Merluccius merluccius & Symphurus ligulatus \\
\hline Cepola macrophthalma & Microchirus ocellatus & Symphurus nigrescens \\
\hline Cerastocopelus maderensis & Microchirus variegatus & Symphurus spp. \\
\hline Chlorophthalmus agassizii & Micromesistius poutassou & Synchiropus phaeton \\
\hline Citharus linguatula & Molva dipterygia & Syngnathus acus \\
\hline Coelorhynchus coelorhynchus & Monochirus hispidus & Syngnathus spp. \\
\hline Conger conger & Mugil cephalus & Synodus saurus \\
\hline Dactylopterus volitans & Mullus barbatus & Trachinus araneus \\
\hline Deltentosteus quadrimaculatus & Mullus surmuletus & Trachinus draco \\
\hline Dentex dentex & Muraena helena & Trachinus radiatus \\
\hline Dentex gibbosus & Nettastoma melanurum & Trigla lucerna \\
\hline Dentex macrophthalmus & Nezumia sclerorhynchus & Trigla lyra \\
\hline Dentex maroccanus & Notacanthus bonapartei & Trigloporus lastoviza \\
\hline Diplodus annularis & Ophichthus rufus & Trisopterus minutus capelanus \\
\hline Diplodus vulgaris & Pagellus acarne & Uranoscopus scaber \\
\hline Echelus myrus & Pagellus bogaraveo & Zeus faber \\
\hline Epigonus constanciae & Pagellus erythrinus & \\
\hline
\end{tabular}


Table A2. List of Chondrichthyes, Crustaceans and Cephalopod species included in the analysis.

\begin{tabular}{|c|c|c|}
\hline Chondrichthyes & Ebalia granulosa & Pontocaris lacazei \\
\hline Centrophorus granulosus & Ergasticus clouei & Pontophilus norvegicus \\
\hline Centrophorus uyato & Ethusa mascarone & Pontophilus spinosus \\
\hline Chimaera monstrosa & Eurynome aspera & Processa canaliculata \\
\hline Dalatias licha & Gennadas elegans & Rissoides desmaresti \\
\hline Dasyatis pastinaca & Goneplax rhomboides & Rissoides pallidus \\
\hline Etmopterus spinax & Homola barbata & Scyllarides latus \\
\hline Galeorhinus galeus & Inachus communissimus & Solenocera membranacea \\
\hline Galeus melastomus & Inachus dorsettensis & Squilla mantis \\
\hline Heptranchias perlo & Inachus sp. & Stenopus spinosus \\
\hline Mustelus mustelus & Inachus thoracicus & \\
\hline Myliobatis aquila & Latreillia elegans & Cephalopoda \\
\hline Oxynotus centrina & Liocarcinus depurator & Abralia veranyi \\
\hline Raja asterias & Lysmata seticaudata & Alloteuthis media \\
\hline Raja brachyura & Macropipus tuberculatus & Alloteuthis subulata \\
\hline Raja clavata & Macropodia longipes & Bathypolypus sponsalis \\
\hline Raja miraletus & Macropodia longirostris & Eledone cirrhosa \\
\hline Raja montagui & Macropodia rostrata & Eledone moschata \\
\hline Raja naevus & Maja goltziana & Illex coindetii \\
\hline Raja oxyrinchus & Maja squinado & Loligo forbesi \\
\hline Raja polystigma & Medaeus couchi & Loligo vulgaris \\
\hline Raja radula & Munida iris & Neorossia caroli \\
\hline Raja rondeleti & Munida rugosa & Octopus macropus \\
\hline Raja undulata & Munida sp. & Octopus salutii \\
\hline Scyliorhinus canicula & Nematocarcinus ensifer & Octopus vulgaris \\
\hline Squalus acanthias & Nephrops norvegicus & Pteroctopus tetracirrhus \\
\hline Squalus blainville & Palicus caronii & Rondeletiola minor \\
\hline Torpedo marmorata & Parapenaeus longirostris & Rossia macrosoma \\
\hline Torpedo nobiliana & Parthenope macrochelos & Scaeurgus unicirrhus \\
\hline \multirow[t]{2}{*}{ Torpedo torpedo } & Parthenope massena & Sepia elegans \\
\hline & Pasiphaea sivado & Sepia officinalis \\
\hline Crustacea & Penaeus kerathurus & Sepia orbignyana \\
\hline Alpheus glaber & Pilumnus spinifer & Sepietta neglecta \\
\hline Aristaeomorpha foliacea & Pisa armata & Sepietta oweniana \\
\hline Aristeus antennatus & Plesionika acanthonotus & Sepietta spp. \\
\hline Bathynectes maravigna & Plesionika antigai & Sepiola affinis \\
\hline Calappa granulata & Plesionika edwardsii & Sepiola intermedia \\
\hline Calappa pelii & Plesionika gigliolii & Sepiola ligulata \\
\hline Calocaris macandreae & Plesionika heterocarpus & Sepiola rondeleti \\
\hline Chlorotocus crassicornis & Plesionika martia & Sepiola spp \\
\hline Dorippe lanata & Polycheles typhlops & Todaropsis eblanae \\
\hline Dromia personata & Pontocaris cataphractus & \\
\hline
\end{tabular}

